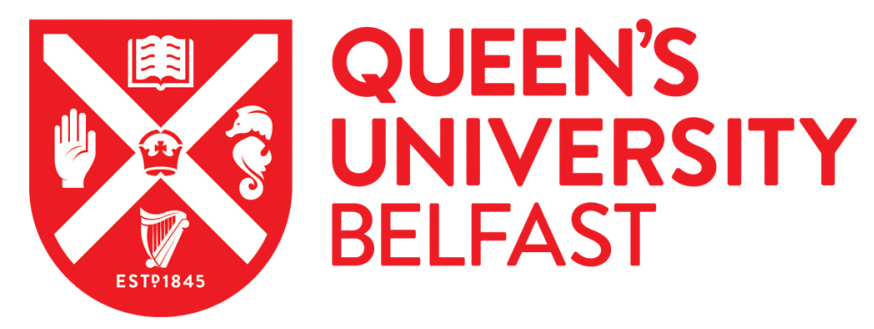

\title{
Broadening the Scope and the Norms of EU Gender Equality Law: Towards a Multidimensional Conception of Equality Law
}

Schiek, D. (2005). Broadening the Scope and the Norms of EU Gender Equality Law: Towards a

Multidimensional Conception of Equality Law. Maastricht Journal of European and Comparative Law, 12(4), 427466. http://heinonline.org/HOL/Page?handle=hein.journals/maastje $12 \&$ div $=30 \& g$ sent $=1 \&$ collection=journals

Published in:

Maastricht Journal of European and Comparative Law

Document Version:

Early version, also known as pre-print

Queen's University Belfast - Research Portal:

Link to publication record in Queen's University Belfast Research Portal

Publisher rights

Copyright 2005 Maastricht Journal of European and Comparative Law.

\section{General rights}

Copyright for the publications made accessible via the Queen's University Belfast Research Portal is retained by the author(s) and / or other copyright owners and it is a condition of accessing these publications that users recognise and abide by the legal requirements associated with these rights.

Take down policy

The Research Portal is Queen's institutional repository that provides access to Queen's research output. Every effort has been made to ensure that content in the Research Portal does not infringe any person's rights, or applicable UK laws. If you discover content in the Research Portal that you believe breaches copyright or violates any law, please contact openaccess@qub.ac.uk. 


\title{
BROADENING THE SCOPE AND THE NORMS OF EU GENDER EQUALITY LAW: TOWARDS A MULTIDIMENSIONAL CONCEPTION OF EQUALITY LAW
}

\author{
DAGMAR SCHIEK ${ }^{*}$
}

\section{$\$ 1 . \quad$ INTRODUCTION}

Introducing Article 13 and Article 3 (2) EC, the Treaty of Amsterdam fundamentally changed EU equality law, adding the prospect of multiplying the grounds of forbidden discrimination and their scope of application and at the same time creating a positive obligation on the part of the European Community 'to eliminate inequalities, and to promote equality, between men and women'. ${ }^{1}$ Both provisions are placed in part one of the Treaty, under the heading 'principles', enhancing their relevance for interpreting the Treaty norms and secondary law.

* Jean Monnet Professor of European Economic Law at Carl von Ossietzky University of Oldenburg (Germany). This article began as a presentation at the conference 'Progressive implementation; new developments in European Union gender equality law' in Den Haag. I would like to thank Prof. Rikki Holtmaat (University of Leiden) and Wilhelmien Ruygrok (E-Quality) for making this event possible and the participants for inspiring discussions. Thanks are also due to the editor of this special issue, Prof. Tamara Hervey (University of Nottingham) for patient editing and suggestions to enhance precision. Finally, I would like to thank Ulrike M. Vieten, M.A. (University of East London) for sharing her knowledge on sociological approaches to multidimensionality. The responsibility for any errors remains with the author.

1 This clause has become known as the gender mainstreaming clause, containing a definition of gender mainstreaming as combating gender inequality and promoting gender equality in all policy areas. This does not mean that mainstreaming 'other equalities' will never become an objective of the European Union (for some suggestions see J. Shaw, Mainstreaming Equality in European Law and Policy Making, commissioned by European Network Against Racism, Brussels 2004). The relevant provisions of the Treaty Establishing a Constitution for Europe, however, seem to deepen the division between gender equality law on the one hand and the combating of discrimination based on sex, racial or ethnic origin, religion or belief, disability, age or sexual orientation on the other. As regards gender equality, the mainstreaming clause is maintained, but granted its own article (III-116). As regards nondiscrimination, Article III-118 establishes an active obligation on the part of the EU to combat discrimination while defining and implementing its policies. This means that under the Constitutional Treaty there are two active obligations as regards gender equality: combating sex discrimination and furthering equality. 
These principles are here presented as being common principles of EU equality law. Of course, the impetus of Article 13, which enables the Member States to take measures to 'combat discrimination', is somewhat different from an obligation to further equality (Article 3 (2)). Combating discrimination, the Member States aim to diminish negative social phenomena, whereas the Community, while promoting equality, strives towards a positive aim. Nonetheless, in Community law the combating of discrimination and the aim of equality are closely related. ${ }^{2}$ As yet, three secondary law instruments have been based on Article 13 EC Treaty. ${ }^{3}$ According to their titles, their shared aim is 'equal treatment of persons' - irrespective of race or ethnic origin, religion and belief, age, disability, sexual orientation and sex. While their demands on the national legislators go beyond a mere formal concept of equal treatment, encompassing more substantive aims such as 'putting into effect the principle of equal treatment', combating discrimination beyond the public sphere and even furthering equality in practice, ${ }^{4}$ they focus on persons as opposed to goods, services or other non-human categories. Focussing on human beings, non-discrimination law aims, at a substantive level, to eliminate such differentiations between persons that are based on certain characteristics and that would fully or partly exclude persons from resources, rights or opportunities to act. Combating discrimination against persons predominantly requires equal treatment, albeit in a substantive and not merely formal sense. Regarding gender equality, the stated aim of eliminating inequalities between women and men in Article 3 (2) EC is probably not meant literally, as some differences between women and men are certainly beyond the regulatory powers of the EU institutions. Consequently, Article 3(2) EC strives for gender equality as a positive aim of non-discrimination law instead of obliging the institutions to pursue formal equal treatment of women and men. Accordingly, gender equality could also be captured as the principle of equal treatment of persons irrespective of gender - as is witnessed by the aims of Directive 2004/113/EC.

Equal treatment of persons irrespective of certain characteristics (the forbidden grounds of discrimination) can thus be presupposed as the common aim of a positive obligation to pursue equality and the competence to combat discrimination. Such equal treatment is also the principal aim of EU equality law and EU non-discrimination law. Both notions are used interchangeably in the following.

2 E. Holmes, 'Anti-Discrimination Rights without Equality' 68 Mod. L. Rev. 175 (2005), makes the point that equality and non-discrimination are not related at all on the level of principle. While brilliantly argued, this proposition is not shared here.

3 Directive 2000/43/EC of 29 June 2000, implementing the principle of equal treatment between persons irrespective of racial or ethnic origin, [2000] OJ L 180/22, Directive 2000/78/EC of 27 November 2000, establishing a general framework for equal treatment in employment and occupation, [2000] OJ L 303/ 16 and Directive 2004/113/EC of 13 December 2004, implementing the principle of equal treatment between men and women in the access to and supply of goods and services [2004] OJ L 373/37.

4 For a detailed analysis of the directives' aims in relation to dualities of equality see D. Schiek, 'A New Framework of Equal Treatment of Persons in EC Law' 8 European Law Journal 290 (2002). 
The aim of this article is to discuss some consequences of placing the combating of discrimination and the promotion of equality among the principles of Community law. The focus is firstly on the ensuing widening of the scope of EU (gender) equality law and secondly on the increase of grounds of forbidden discrimination. In concluding, some steps towards a multidimensional conception of equality law are proposed.

\section{\$2. BROADENING OF SCOPE - BEYOND EMPLOYMENT AND OCCUPATION}

Until 2000, EC equality legislation was more or less a subsection of EU social policy, covering most aspects of employment and occupation. ${ }^{5}$

\section{A. SOCIAL ADVANTAGES, EDUCATION, SUPPLY OF GOODS AND SERVICES}

When Article $13 \mathrm{EC}$ was first used as a competence norm, EU equality law encompassed areas other than employment and occupation: Directive 2000/43/EC, 'implementing the principle of equal treatment between persons irrespective of racial or ethnic origin' (hereinafter the Anti-racism Directive), covered social advantages, education and supply

5 The principle of equal treatment irrespective of sex is applicable to access to employment and employment conditions other than pay, including training (Directive 76/207/EEC), membership of and involvement in organisations of workers and employers and professional organisations (Directive 76/ 207/EEC as amended by Directive 2002/73/EC), certain aspects of self employed occupations (Directive 86/613/EEC and Directive 76/207/EEC as amended by Directive 2002/73/EC) and social security issues (Directive 79/7/EEC). As regards national discrimination, the situation is similar: the prohibition to discriminate on grounds of a nationality of a EU Member State is one of the corner stones of the EC Treaty and established generally through Article $12 \mathrm{EC}$ as well as specifically for workers, self-employed persons and those providing or receiving services under Articles 39, 43 and 49/50 EC. The ECJ's case law has considered the fundamental freedoms to guarantee equal treatment regarding 'social advantages' that were connected to their material scope, and also protected 'service receivers' from nationality discrimination (for extended coverage see G. Davies, Nationality Discrimination in the European Internal Market (Kluwer, 2002); on more recent developments G. Davies, 'Any Place I Hang my Head or: Residence is the New Nationality' 22 Eur.L. J. 43 (2005)). Secondary law, however, focused on employment and occupation as well as on social security (Regulation 1612/68/EEC of the Council of 15 October 1968 on freedom of movement for workers within the Community [1968] OJ L 257/2 on employment and regulation EEC 1408/71 of the Council of 14 June 1971 on the application of social security schemes to employed persons and their families moving within the Community [1971] OJ L $149 / 2$ on social security. Regulation 1612/68, however, also covered access to housing and to union services (Article 8). In addition, Directive 2004/38/EC of the European Parliament and of the Council of 29 April 2004 on the right of citizens of the Union and their family members to move and reside freely within the territory of the Member States ([2004] OJ 229/34), now grants a right of equal treatment with nationals of a host member state to all Union citizens and their family members 'within the scope of the Treaty', excluding social assistance for the first three month of residence and any maintenance aid for studies of vocational training except for employees and self-employed persons and their family members. 
of goods and services, which are available to the public, including housing. Some four years later, in 2004, EU gender equality law followed suit: Directive 2004/113/EC, 'implementing the principle of equal treatment between men and women in the access to and supply of goods and services' (hereinafter Gender Equality Goods and Services Directive) extended the prohibition of discrimination on grounds of sex to goods and services, but not to education and social advantages (Article 3). ${ }^{6}$ The principle of equal treatment in the provision of and access to goods and services was maimed by extensive exemption clauses in favour of the insurance industry (Article 5).

The comparison between these two directives' scope of application appears to mirror the hierarchy of equalities that has been rightly criticised by various authors. ${ }^{7}$ This hierarchy points to conceptual issues that are worthy of further exploration. The following will focus on the question of why extending equality law, and especially gender equality law, beyond employment and occupation is so burdensome.

\section{B. EQUAL TREATMENT OF PERSONS AS SOCIAL LAW, CONSTITUTIONAL LAW OR A GENERAL PRINCIPLE?}

First of all, the question arises as to whether equality law has truly grown beyond the confines of social policy by extending its scope of application towards social advantages, education and goods and services. Bell submits that the directives on equal treatment of persons, rather than a step beyond the confines of the social, are steps towards a new conception of EU social policy or EU social regulation. ${ }^{8}$ Barnard seems to imply that the new areas are merely annexed to employment and occupation, which are considered as key factors to integration. ${ }^{9}$ If integration is the key to EU equality law's telos, it might well be considered as a subdivision of the welfare state principle. The main aim of the welfare state is, after all, integration of society. ${ }^{10}$ However, European integration, having started as economic integration, is certainly not confined to the welfare state in a narrow sense. Rather, European integration encompasses a wide number of areas relevant to the social, economic and cultural activities of Europe's citizens, including economic policy,

6 On the (at times impossible) distinction between education and services see note 14 .

$7 \quad$ M. Bell and L. Waddington 'Reflecting on inequalities in European equality law' 28 Eur. L. Rev. 349 (2003); D. Schiek, 'A New Framework of Equal Treatment of Persons in EC Law', particularly 308-311; S. Fredman 'Equality: A New Generation?' 30 Ind. L. J. 145 (2001), 151, 157-158 in particular.

$8 \quad$ M. Bell, 'Beyond European Labour Law? Reflections on the EU Racial Equality Directive', 8 Eur. L. J. 384 (2002), 387: 'shift towards a broader conception of European social law'; 390 'styles of European social regulation'.

9 C. Barnard, 'The Changing Scope of the Fundamental Principle of Equality?' 46 McGill L. J. 955 (2001), 968.

10 More conceptually on aims of the welfare state, D. Schiek, 'Art. 20 Abs. 1-3, IV Sozialstaatsprinzip (Commentary on the German Constitution's welfare state principle)' in E. Denninger, et al. (eds.) Gemeinschaftskommentar zum Grundgesetz - Reihe Alternativkommentare, (Luchterhand , 3rd ed. 2001), 2nd volume, 1-83. 
competition policy, commercial policy, environmental policy, consumer policy and employment policy, to name some of the divergent areas nowadays encapsulated by European integration. Considering that Article $13 \mathrm{EC}$, which is after all the basis for the new EU equality legislation, is situated in the introductory chapter of the EC Treaty, and more precisely exactly between the provision on national discrimination on the one hand and on the definition of the internal market on the other, one would more easily draw the conclusion that EU equality law is meant to go beyond social policy and to embrace all EU policies in the same way.

Broadening the scope of EU level welfare policies is not the only alternative to classifying anti-discrimination law as a sub-division of employment law. For the UK context, a constitutional as opposed to an employment law perspective on equality law has been proposed, as the term seems more adequate for encompassing different areas of law, such as family law, employment law, criminal law, judicial review and property law. ${ }^{11}$ From a continental perspective, the term 'constitutional' is not without is shortcomings, however. All constitutions of continental Member States contain norms on equality and/or discrimination. However, these are not considered as binding on economic actors, leaving the 'public sphere proper' as the adequate area of application for non-discrimination law. ${ }^{12}$

Obviously, this limitation would not capture the spirit of EU equality law, as the Community legislator is not content with addressing discrimination in the state sphere: the directives' scope of application is not restricted to law making or discriminatory exclusion from goods and services offered by the Member States themselves. True to the EU's still dominant focus on market integration, the Community's non-discrimination law focuses on this field as well. If non-discrimination law were characterised as a constitutional principle in the continental tradition as described above, EU equality law's focus on non-governmental activities might be lost.

The equality directives endeavour to engender civilised behaviour among citizens in their non-state centred activities through law; ${ }^{13}$ in other words they aim to ensure a civil society which is inclusive and diverse rather than exclusive and particular. Their scope of application encompasses governmental activities, as governments are offering services to their citizens, ${ }^{14}$ but the main impact is on relations between citizens. At the same time,

11 N. Bamforth, 'Conceptions of Anti-Discrimination Law' 24 O. J. L. S. 693 (2004).

12 This is behind much of the outspoken critique against any anti-discrimination act in German doctrine. For an especially blunt example see E. Pickert, 'DEBATE: Anti-discrimination as a Program of Private Law ?' 4 German Law Journal 772 (2003) (www.germanlawjournal.com), 778-779, a translation of E. Pickert, 'Antidiskriminierung als Zivilrechtsprogramm?' 58 Juristenzeitung 540 (2003).

13 D. Schiek, 'A New Framework of Equal Treatment of Persons in EC Law', 294.

14 Depending on the breadth of the service definition, educational services would be covered by the 'access to and provision of services' clause. However, a systemic interpretation of Directive 2000/43/EC and Directive 2004/113/EC would lead to the conclusion that the provision of education, social advantages and social security would not qualify as services under the anti-discrimination directives; otherwise the specific inclusion of these areas in Directive 2000/43/EC would not make sense. On the other hand, ECJ 
the directives go beyond a pure logic of engendering the internal market. While there is a claim for having uniform rules on non-discrimination beyond nationality from such a $\operatorname{logic}{ }^{15}$ it does not require legal rules that raise the level of protection from discrimination. The directives aim at pursuing certain values in the market place, elevating human rights from their restriction on state action to general principles of law, or to fundamental rights proper. ${ }^{16}$ This is portrayed as one of the elements of 'constitutionalizing contract law'. ${ }^{17}$ Again, the danger of unnecessarily stressing a dichotomy between the public and private is inherent in this term.

Accordingly, it is suggested here that to consider the principle of equal treatment of persons irrespective of a set of ascribed characteristics as a general principle of law, which is to be applied to all areas of law, irrespective of whether the main actors in the specific field of law are public or non-state actors. This understanding is an adequate response to a polity which is neither confined to one nation state nor striving towards becoming another super-nation state. The European Union is a multi-level polity, ${ }^{18}$ based on its Member States, but also on the peoples of Europe. In this polity, aimed at engendering trans-national and European markets and societies, the focus of law needs to surpass the relationship between states and citizens. Adapting to the fact that trans-national markets are governed by non-state actors, EU law, especially when derived from the Community pillar, more often than not regulates relations between citizens (as economic actors). Under this perspective, non-discrimination and equality law would have to be considered as general principles governing the activities of those acting on the internal market and in the European polity, irrespective of national orders or public law elements.

case law has had a tendency to broaden the scope of services under Article 49, which may lead to including education under this provision (see E. Ellis, EU Anti-Discrimination Law (OUP 2004), 256, with further references). This then would lead to a systemic interpretation of the notion 'services' in primary and secondary law. Presently, there is only one precedent in ECJ case law on education and Article 49 EC, which excludes education from its scope of application, the Court not considering education and social security as services in the sense of Article $50 \mathrm{EC}$, being normally provided for remuneration (ECJ case 263/86 Belgium v Humbel [1988] ECR 5365).

15 See R. Nielsen, Gender Equality in European Contract Law (DØJF 2004), 27: 'If, for example, the premium in a contract for life insurance can lawfully be based on sex-related actuarial factors in one Member State but not in another the free movement of services will be hindered'.

16 Accordingly, Nielsen refers to a fundamental rights perspective as opposed to an internal market perspective. Gender Equality in European Contract Law, 32.

17 See Study Group on Social Justice in European Private Law, 'Social Justice in European Contract Law: a Manifesto' 10 Eur. L. J. 653 (2004), 667-668, mentioning, inter alia, equality, diversity and social inclusion as values against which freedom (including freedom of contract) need to be balanced.

18 The vast amount of socio-political and legal writing would exceed the capacity of a single note. Some examples: L. Hooghe and G. Marks, Multi-level Governance and European Integration (Rowman \& Littlefield 1996); B. Kohler-Koch and R. Eising (eds.), The Transformation of Governance in the European Union (Routledge 1999); N. Bernard, Multilevel Governance in the European Union (Kluwer, 2000). For recent perspectives see 9 Geopolitics 3 (2004) (special issue on post-national politics in the European Union). 
Broadening the Scope and the Norms of EU Gender Equality Law: Towards a Multidimensional Conception of Equality Law

\section{EQUALITY, NON-DISCRIMINATION AND FREEDOM OF CONTRACT}

One benefit of the approach of integrating non-discrimination and equal treatment requirements as general principles into private contract law is that it would reduce the reluctance to accept any widening of equality law's scope of application. Presently, there is a strong conviction among some contract law scholars that equality law has no lawful claim to be integrated in any area of law governed by freedom of contract. From this view, the inclusion of the provision of goods and services into Directive 2000/43/EC was already a major mistake, ${ }^{19}$ partly alleviated by including the 'available to the public' exception, which has to be interpreted as widely as possible in order to remedy the worst of this eternal sin against freedom of contract. Accordingly, this clause is read so as to exclude a multitude of contractual settings from Directive 2000/43/EC's scope of application. ${ }^{20}$ Even authors who would not oppose the widening of the scope of equality law beyond labour law often perceive of freedom of contract and non-discrimination law as antonyms. They would submit that public law issues such as non-discrimination should, in principle, prevail, as the balancing of freedom of contract with public welfare is a constitutional issue. ${ }^{21}$ Although supportive of prohibiting discrimination in the access to and provision of goods and services, these authors also strengthen the perception that non-discrimination and contract law are indeed irreconcilable. Accordingly, hierarchies of equality are easily justifiable, as are exceptions from non-discrimination clauses in contract law. If equality law is to grow beyond the confines of social law, a fundamental positioning on the question of whether contract law as such can or cannot accommodate non-discrimination law among its principles is necessary. ${ }^{22}$

The traditional position that contract law and non-discrimination law are antonyms rests on the assumption that formal freedom of contract is the main leitmotif of contract law. This perception is, however, misguided. For some time, contract law in the EU Member States has been informed by different, at times contradictory, paradigms. As is witnessed by the Lando-Principles, ${ }^{23}$ there is a strong tradition of relying on fairness and

19 See E. Pickert, 'DEBATE: Anti-discrimination as a Program of Private Law ?' 772.

20 G. Thüsing, 'Richtlinienkonforme Auslegung und unmittelbare Geltung von EG-Richtlinien im AntiDiskriminierungsrecht?', 48 Neue Juristische Wochenschrift 3441 (2003).

21 Baer, 'Ende der Privatautonomie oder grundrechtlich fundierte Rechtssetzung? Die deutsche Debatte um das Antidiskriminierungsrecht', 35 Zeitschrift für Rechtspolitik 291 (2002); J. Neuner 'Diskriminierungsschutz durch Privatrecht' 58 Juristenzeitung 57 (2003).

22 See D. Schiek, Freedom of Contract and a Non-Discrimination Principle - Irreconcilable Antonyms? in T. Loenen \& P. Rodrigues (eds.) Non-Discrimination Law: Comparative Perspectives (Kluwer 1999), 77.

23 O. Lando \& H. Beale (eds.) Principles of European Contract Law, Part I and II (Kluwer 2000). According to Article 1:102, entitled 'Freedom of Contract', parties are free to enter into a contract and to determine its contents, subject to the requirements of good faith and fair dealing and the mandatory rules established by the principles. There are decisive differences between these principles and the UNIDROIT principles, according to which freedom of contract is granted unconditionally, and also with the Academy of European Private Lawyers' preliminary draft of a European Contract Code, according to which the parties are free to decide on the contents of a contract within the limits imposed by mandatory 
reasonableness even in contracts concluded between businesses. EU contract law adds the principle of information prior to contracting. ${ }^{24}$ These are just examples for a shift from subjective towards objective aspects being decisive for the modern contract law paradigms,${ }^{25}$ which are less concerned with formal autonomy than with guarding the capacities of the market place as an institution. Modern contract law thus rests on the assumption that freedom of contract is a legal frame for the capabilities of action for individuals. Under these views, contract law's dominant aim is to provide for a means of exchange in markets. To fulfil this function, contract law has to provide a balance between formal and substantive aspects of freedom of contract. Integrating a prohibition of discrimination among its principles will serve to provide an equal basis for all individuals to participate in market exchange. Inter alia, it will enhance the functioning of markets rather than restricting it. ${ }^{26}$

This fundamental positioning is by no means irrelevant to the prospects of gender equality becoming an accepted principle of contract law. Given the limited number of those who are perceived as being discriminated against on grounds of race or ethnic origin in Europe, a prohibition on discrimination in the provision of goods and services is capable of being accepted by business, albeit grudgingly. Those perceived as being female are in much higher numbers. Accordingly, continuing to discriminate against women in areas such as costs of insurances or business credits ${ }^{27}$ will be much more profitable than the same practice applied to ethnic minorities. Whether gender discrimination is accepted as a legitimate condition under which to exercise one's freedom of contract is thus the reality test for equality law to achieve a true acceptance within the law of the Internal Market proper and, as a consequence, to make substantial progress beyond employment law.

\section{THE MARKET PLACE, INFORMATIONAL JUSTICE AND DISCRIMINATION BASED ON ACTUARIAL FACTORS}

As is witnessed by the intense lobbying of the insurance industry against Directive 2004/ $113 / \mathrm{EC}$ and the resulting (exceptional) justifications of discrimination against women

rules, morals and public policy. The Lando principles, being based on the most extensive comparative work, appear to be more representative of European common values as regards contract law. It is, however, worthy of note that according to the AEPL-Code there is no freedom whatsoever to chose one's contract partner. The AEPL Code is published in O. Radley-Garner et al. (eds.) Fundamental Texts on European Private Law (Hart Publishing 2003).

24 For a detailed account on this see D. Schiek, Differenzierte Gerechtigkeit - Diskriminierungsschutz und Vertragsrecht (Nomos 2000), 323-357.

25 R. Nielsen, Gender Equality, 115.

26 For a detailed analysis of general principles in German contract law and the possibility to base the principle of non-discrimination as an additional layer on these see Schiek, Differenzierte Gerechtigkeit, 428-455.

27 Nielsen, Gender Equality, 21-23. 
based on actuarial factors, economic gains may be expected from this form of discrimination. Actuarial factors are of course central to the business of providing insurance, but not restricted to this area. Consequently, the generous exception for actuarial discrimination in Article 5 of Directive 2004/113/EC extends to 'related financial services'. Beyond this, actuarial factors may be used to grant or withhold credit facilities and thus to decide upon access to a variety of consumer goods.

In the case of gender, actuarial practices are most easily employed as gendered statistics have never been criticised on moral grounds and their availability has, in fact, increased upon demands of equality law. Without gender specific statistics, there would be no impact assessment of any new legislation, and the prohibition of indirect gender discrimination depends on statistical data. The wide-spread use of gender as a nonsuspect criterion in any data sampling exercise facilitates market segmenting strategies in this respect, resulting in gender specific services and pricing.

Analysing non-discrimination law from an economic perspective, many authors come to the conclusion that - while discrimination based on psychological preferences is more often than not ineffective ${ }^{28}$ - there remains a case for statistical discrimination. The term 'statistical discrimination' refers to a business strategy which uses easily perceivable characteristics as a proxy for other, usually hidden, traits. If women drop out of the labour market in favour of depending on other people's earnings more often than men, an employer would not hire them for any position where long-term employment is required. ${ }^{29}$ If an employer knows that ethnic minority applicants' formal education is, on average, of a lower quality than that of other applicants, preferring the other applicants would be rational discrimination. 'Statistical discrimination' would only promise extra profits if and insofar as finding information on the fact one is really interested in is far more expensive than discrimination, or even impossible. ${ }^{30}$ While 'statistical discrimination' may be a term for hiding prejudice, ${ }^{31}$ insurers do purport to have a reliable pool of data on which to base their discriminatory market practices. The decisive question is whether gender based statistics may constitute a legitimate reason for detrimental treatment of women or men. ${ }^{32}$ In actuarial practices, gender specific data is

28 The classical foundation for this has been given by G. Becker, The Economics of Discrimination (University of Chicago Press, 2nd ed. 1973), chapter 3, who considers that anyone who would avoid contact with a class of people would pay a 'discrimination tax'.

29 See R. Posner, 'An Economic Analysis of Sex Discrimination Laws' 56 University of Chicago Law Review 1311(1989), 1320.

30 See R. Epstein, Forbidden Grounds. The Case against Employment Discrimination Laws (Harvard University Press, 1992), 33-37.

31 See A. Engert, 'Allied by Surprise? The Economic Case for an Anti-discrimination Statute', 4 German Law Journal 685 (2003), 690, referring to evidence that 'many landlords believe that ethnic origin is an indicator for how (un-)reliable a tenant is going to be'.

32 It should be stressed that, although the insurance industry repeatedly raises the issue of lower tariffs for women in car insurances, most gender specific insurance tariffs work to the detriment of women, notably as regards health insurance and private pension schemes. 
used for the purpose of stabilising gender differences. If women lived longer than men on average in $1980,{ }^{33}$ any individual woman is required to pay higher contributions to her private pension plan than any individual man in 1998, although she may die younger due to gender specific stress resulting from the so called double burden of employment and family work. The effect of discrimination based on actuarial practices is to base treatment of a person not on his or her individuality but on her perception as the average of a group to which she is deemed to belong. ${ }^{34}$ A prohibition of direct discrimination would normally aim at prohibiting this very form of imposing virtual group membership on an individual and using this 'group membership' as a justification for withholding an advantage from an individual. If this is still one of equality law's purposes, it seems odd that the insurance industry's arguments based on group average are accepted so readily.

One of the purposes of equality law is deeply individualistic: no one shall be judged on the basis of assumptions in line with group characteristics. Again, the insurance argument is a perfect test case. Do we disallow only decisions based on those group characteristics that are statistically proven to be false, as Article 5 para. 2 of Directive 2004/113/EC proposes? Or do we consider that equality law shall defend the right of any individual not to be treated as member of an ascribed collective? If the latter question were answered in the negative, gender equality law would most certainly soon lose its raison d'être.

Retaining this individualistic purpose is not only decisive for the insurance case, but also for any marketing practice relying on statistics. As such practices are becoming increasingly common, a strict conception of non-discrimination law is required in the event that it becomes relevant for market practices.

\section{E. BROADENING THE SCOPE - PERSPECTIVES FOR THE FUTURE?}

Broadening the scope of EU equality law has been an incremental and almost haphazard process so far. Including areas other than employment law in the Anti-racism Directive seems to have gone unnoticed in the speedy process of adopting this piece of legislation. However, when gender equality was to follow suit four years later, resistance to this process was more determined. The easy success of the lobbying activity against gender equality demonstrates that for EU equality law to expand beyond the 'social ghetto', a more carefully reasoned approach is needed. This principled discussion is yet to be had. Relying on the rhetoric of constitutionalisation will not be sufficient to successfully challenge traditional perceptions of contract law. Rather, the messages of equality law need to penetrate the deep layers of contract law if racist and sexist exclusion from the market place is to be tackled seriously.

The longevity data from 1980 were used by the German insurance industry until 1998.

34 Proponents of the 'law-and-economic' camp purport that the disempowering effects of allowing group membership to decide will, in the long run, have negative macro-economic effects except in relation to insurance discrimination against women; see Engert, 'Allied by Surprise? The Economic Case for an Anti-discrimination Statute', 695-696. 
Broadening the Scope and the Norms of EU Gender Equality Law: Towards a Multidimensional Conception of Equality Law

\section{\$3. BROADENING OF NORMS - MULTIPLYING GROUNDS OF FORBIDDEN DISCRIMINATION}

The EU institutions used the prospect of multiplying the grounds of forbidden discrimination opened up by Article 13 to focus on other equalities than gender while adopting the Anti-racism Directive and Directive 2000/78/EC establishing a general framework for equal treatment of persons in employment and occupation (hereinafter Framework Directive). Both directives introduced new approaches to the legal framing of equality; for example, new definitions of direct and indirect discrimination as well as of harassment. ${ }^{35}$ All that those promoting gender equality law could seemingly hope to achieve was to transfer this 'progress' to gender equality law. By adopting Directives $2002 / 73 / \mathrm{EC}^{36}$ and 2004/113/EC, the EC legislator demonstrated that it had some difficulties in completing this transfer: ${ }^{37}$ the resulting hierarchies of equality law have already been mentioned. Any conclusion that the diminishing of the relevance of gender equality was an inevitable consequence would, however, not adequately mirror the conceptual potential of multiplying grounds of forbidden discrimination. There is at least the theoretical opportunity for this broadening of norms to improve equality law in a way that will ultimately better serve the purpose of combating discrimination against women.

The analysis of conceptual consequences of multiplying grounds of forbidden discrimination being a suitable theme for an entire monograph in itself, this part of the article aims to open the field for discussion. It starts by discussing reasons for and approaches to increasing the number of grounds of forbidden discrimination, distinguishing between an 'additive' and an 'integrated' approach. Next, the possible consequences of the 'additive' approach are expanded upon, considering arguments for different rationales behind different (single) grounds and the question whether these differences require different conceptions of equality law. Following this, the opportunities of an 'integrated' approach are considered, and the potential of reconciling different rationales of equality law and law's responses to intersectionality discussed. A summarizing section will identify the questions to be answered for EU non-discrimination and equality law as a consequence of the multiplication of grounds, leading over to the concluding section on perspectives for a multidimensional conception of EU equality law.

35 See Schiek, 'A New Framework of Equal Treatment of Persons in EC Law', 290.

36 Of 23 September 2002 amending Council Directive 76/207/EEC on the implementation of the principle of equal treatment for men and women as regards access to employment, vocational training and promotion, and working conditions, [2002] OJ L 269/15.

37 For a critical assessment of the directives from a gender equality perspective see A. Masselot \& E. Torella, 'The Future of Sex Equality' in T. Trimedas \& P. Nebbia (eds.) European Law for the Twenty-First Century (Hart Publishing, 2004), 333; see also L. Waddington, 'The Development of a New Generation of Sex Equality Directives' 11 Maastricht Journal of European and Comparative Law 3 (2004). 


\section{A. REASONS FOR AND APPROACHES TO MULTIPLYING OF GROUNDS}

The constant expansion of grounds of forbidden discrimination is a feature common to international ${ }^{38}$ and EU equality law. ${ }^{39}$ The reasons for and approaches to this expansion are diverse.

In the case of the EU, the expansion has been said to be motivated by dangers of ethnic conflict within an enlarged $\mathrm{EU}^{40}$ and to have been accelerated by a populist rightwing party forming part of the government of a Member State. ${ }^{41}$ While these developments have created a positive political climate in favour of more equality law, the speedy process of adopting Directives 2000/43/EC and 2000/78/EC was clearly spurred by lobbying activities. In fact, detailed proposals for the resulting legislation had been prepared by the Starting Line Group, comprising several lobbying organisations from different member states, predominantly those focusing on racial and ethnic discrimination. ${ }^{42}$ Unsurprisingly, racial and ethnic discrimination enjoys an elevated position within the hierarchies of EU equality law. Other movements have not been idle in lobbying for specific grounds being integrated, among them the 'rainbow movement' for outlawing discrimination against lesbians and gay $\operatorname{men}^{43}$ and different groups working

38 H. Bielfeld/P. Fellmar-Otto, Diskriminierungsschutz in der politischen Diskussion (DIMR 2005), 6.

39 C.f. Barnard, 'The Changing Scope of the Fundamental Principle of Equality?', 965-966, comparing the list of grounds from the Charter of Fundamental Rights for the European Union and Article 13.

40 See Explanatory Memorandum, COM (1999) 565 final, 4, explaining that the directive is intended to provide 'a solid basis for the enlargement of the European Union which must be founded on the full and effective suspect of human rights', adding that enlargement made 'it essential to put into place a common European framework for the fight against racism'.

41 This connection is made by Barnard, 'The Changing Scope of the Fundamental Principle of Equality?', 967, as well as by E. Guild, 'The EC Directive on Race Discrimination: Surprises, Possibilities and Limitations' 29 Ind. L. J. 416 (2000), 416.

42 See I. Chopin, 'The Starting Line Group: A Harmonised Approach to Fight Racism and to Promote Equal Treatment' 1 Eur. J. of Migration and the Law 111 (1999). The first comprehensive lobbying paper by this group was published as early as 1993 (The Starting Line: A Proposal for a Draft Council Directive Concerning the Elimination of Racial Discrimination, 1993).

43 The most influential organization probably being ILGA (see http:/www.ilga.org). With sexual orientation, however, much lobbying is possibly done in a covert way: As there are many homosexuals hiding their choice of life style, it must be assumed that there are a number of them among those lobbying for broadening the scope for more equalities in general. A typical citation for this form of covert lobbying: 'One of the lessons of Article 13 was the ability of more controversial grounds of discrimination to make unexpected progress through seeking inclusion in a broad anti-discrimination instrument' M. Bell, Anti-Discrimination Law and the European Union (OUP 2002), 168-9. On sexual orientation as a ground for discrimination see R. Wintemunte, 'On recognizing new kinds of direct sex discrimination: trans-sexualism, sexual orientation and dress codes’ 60 Mod. L. Rev. 334 (1997); P. Skidmore 'Improving the position of lesbians and gay men at work in the light of the framework directive for equal treatment in employment' 3 Cambridge Yearbook of European Legal Studies 425 (2001). See also Chapter four in Bell, 88-120. 
towards integration of people with disabilities. ${ }^{44}$ The latter groups have seen some success by integrating the specific concept of prohibiting discrimination by denying reasonable accommodation into EU equality law only in favour of their clientele. ${ }^{45}$

As long as the multiplying of grounds is driven by political successes of one-point movements, adding religion and belief, race and ethnicity, sexual orientation, age and disability to gender and nationality, the legislation merely adds more 'protected groups' to the (possible) scope of EU equality law. Under this perspective, EU equality may or may not develop similar structures for each forbidden ground, which implies the possibility of diverging equality laws for different equalities. This approach will be labelled an additive approach to EU equality law in the following.

However, not all those who demand the combating of discrimination and who strive for equality focus on single grounds. Especially as regards gender equality, feminist politics have been said to have gone through three different phases ${ }^{46}$ : the politics of gender equality began with the 'equality stage' ${ }^{47}$ on the basis of a 'sameness approach'48, focusing on eliminating different treatment of women under the premise that women were to be considered as men's equals in most respects. This was followed by a 'difference stage $^{\text {,49 }}$ with its 'diversity approach'50, focusing on differences between women and men and the ensuing responses in law that should make possible equality despite difference. The next step (labelled the 'diversity phase') ${ }^{51}$ of development was then to acknowledge that not all women live under the same circumstances, as their position in society is

44 As regards disability, the European Disability Forum serves as a focus group for lobbyist on this behalf. On the role of lobbying in this regards in developing European Disability Rights see D. Mabbett, 'The Development of Rights -based Social Policy in the European Union: The Example of Disability Rights' 43 J. C. M. St. 97 (2005), 108, recounting how this lobbying group was effectively founded by the European Union itself; see also European Disability Forum, Invisible Citizens - How Can Disabled Persons in the European Union Achieve Equal Rights as Citizens? Summary of the Legal and Economic Implications of a Non-discrimination clause in the European Treaties - A Report by the Legal Expert Working Group (Brussels: EDF 1996). See also L. Waddington, 'The European Community and Disability Discrimination: time to address the deficit of powers?' 12 Disability \& Society 465 (1997).

45 See L. Waddington/ A. Hendricks, 'The Expanding Concept of Employment Discrimination in Europe: From Direct and Indirect Discrimination to Reasonable Accommodation Discrimination' 18 Int. J. Comp. Labour L. Ind. Relations 403 (2002), 413-4, referring to the relevance of reasonable accommodation for other grounds.

46 B. Hernandez-Truyol, 'Querying Lawrence' 65 Ohio State Law Journal 1151 (2004), 1229-1231 with notes 537-541, citing herself from 'Out of the Shadows. Traversing the Imaginary of Sameness, Difference and Relationalism - A Human Rights Proposal’ 17 Wisconsin Women's Law Journal 11 (2002); M. Chamallas, Introduction to Feminist Legal Theory, (Apsen 2nd ed. 2003), 15-97.

47 Term coined by Chamallas, Introduction to Feminist Legal Theory, 15-22.

48 Term coined by Hernandez-Truyol, 'Querying Lawrence', 1230 note 539.

49 Chamallas, Feminist Legal Theory, 39-75.

50 Hernandez-Truyol, 'Querying Lawrence', 1230.

51 Chamallas, Feminist Legal Theory, 77-134. 
determined by different positioning ${ }^{52}$ as well. While the issue of 'women of colour' has dominated the discussion in the US, ${ }^{53}$ there are more 'positionings' to be considered, such as race, ethnicity, social class and sexuality ${ }^{54}$ This last strand of feminism requires protection against discrimination on different grounds as a necessary corollary to gender equality law.

Similarly, critical race theory ${ }^{55}$ has come to acknowledge that racial discrimination takes different forms depending on other 'positionings' of those affected. This acknowledgement has, in fact, been the basis for an expert meeting on gendered aspects of racial discrimination during the world conference against racism. ${ }^{56}$ In theorising ethnic and racial discrimination, different authors have arrived at the conclusion that the categories of 'race' and 'ethnicity' presuppose a conveniently binary division of the world into black and white. For the Americas, theorising the situation of Latinos is said to have led to a LatCrit Approach. ${ }^{57}$ For the UK, several writers demand that more specific efforts be made in researching different forms of discrimination against different ethnic or racial groups. ${ }^{58}$ All these political demands could be answered by an integrated approach to equality law rather than by an additive approach, which is prone to stress one form of discrimination as superior to others.

From these perspectives, the constant expansion of 'forbidden grounds' appears to mirror a multi-faceted reality of human beings. Human beings do not exist as compartmentalised entities, but rather as one person each with different characteristics some of which might fall into the category of personal features serving as starting points for social exclusion or inequality. No single human being is male only and not at the same

52 The term 'positioning' refers to the sociological theory of positionality. Authors use this term and rely on this theoretical framework to stress that any subject is rooted in ethnic, gender, class, cultural or national difference. These 'positionings' are not so much a matter of free choice, but rather mirror how others position the subject in question. Positionality can be ascribed or enforced, in addition to being selected. See, for example, L. Alcoff, 'Cultural Feminism versus Post-Structuralism: The Identity Crisis in Feminist Theory' in L. Nicholson (ed.); The Second Wave: A Reader in Feminist Theory (Routledge, 1997), 330355.

53 See Hernandez-Truyol, 'Querying Lawrence', note 541.

54 See, for example, L. Watkins/ B. Chancer, Gender Race and Class (OUP, 2005); D. Cooper, Challenging Diversity. Rethinking Equality and the Value of Difference, (Cambridge University Press, 2004), 51 (naming race, gender, class and sexuality as the main suspects for organising principles of inequality) and 195 (arriving at the conclusion, that race, socioeconomic class and gender are most pervasive in their capacity to organise inequality, and that the 'hetero/homo divide' might also be acknowledged as having a similar quality).

55 See F. Valdes et al. (eds.), Crossroads, Directions and the New Critical Race Theory, (Temple University Press, 2002), especially the papers on 'crossroads' section A - Race.

56 See K. Crenshaw, Background paper for the expert meeting on the gender related aspects of race discrimination, November 21-24, 2000 (http://www.wicej.addr.com/wcar_docs/crenshaw.html).

57 Hernandez-Truyol, 'Querying Lawrence', 1232-1234.

58 See D. Chalmers, 'The Mistakes of the Good European?' in S. Fredman (ed.), Discrimination and human rights. The case of racism. (OUP, 2001), 222 (note 109 referring to British census data); S. Fredman, Discrimination Law (OUP, 2000), 46-7. 
time ascribed a specific ethnic identity, and no one can be heterosexual without being considered as male or female. Any single person will be affected by each of the different prohibitions of discrimination, either as someone against whom discrimination is likely to work in social reality or as someone whose social position is threatened by effective implementation of equality law. In embracing more than the traditional two grounds, EU equality law would strive to do justice to this reality. This would imply the possibility of legal protection against discrimination on different grounds incrementally developing towards a coherent framework. This approach will be labelled an integrated approach to equality law in the following. ${ }^{59}$

It would not be wise to jump to the conclusion that an integrated approach is the way forward, while a compartmentalised or additive approach has nothing to offer. Rather, one should discuss which shortcomings and advantages are specific to each approach. An additive approach would develop different legal regimes for different equalities, which might be advantageous if different grounds of forbidden discrimination were seen to rest on different rationales for equality law and thus require different conceptions of equality law. Inherent to strategies to regulate for equalities instead of equality, however, is also the danger that some rationales or conceptions are detrimental to some equalities while furthering others. These issues will be discussed next (under B). An integrated approach would appear to be better suited to reconcile any different rationales for different equalities and ultimately to respond to the multi-faceted reality of human beings. These issues will be discussed later (under C), before a tentative conclusion on questions to be addressed by EU equality law will be drawn (under D).

\section{B. MULTIPLYING OF GROUNDS: ISSUES FOR AN ADDITIVE CONCEPTION OF EQUALITY LAW}

\section{Conceptions and rationales}

While theorising equality law, most authors prefer to depict conceptions for equality as a set of dualities, arriving at the conclusion that EU equality law is (and should be) a conceptional hybrid. ${ }^{60}$ Within the set of dualities, a formal conception of equality competes with a substantive conception, as does a symmetric with an asymmetric conception. A third duality positions an individualistic model against a diversity model. Additionally, starting from a wide notion of enforcement and effectiveness, different

\footnotetext{
59 The notion of an 'integrated approach' is taken from K. Zappone, Charting the Equality Agenda. A Coherent Framework for Equality Strategies in Ireland, North and South, commissioned by the Irish and Northern Ireland Equality Commission (June 2001), 63-104.

60 See Schiek, Differenzierte Gerechtigkeit, 74; C. McCrudden, The New Concepts of Equality, ERA 2003 (http://www.era.int/web/en/resources/5_1990_344_file.327.pdf), 18.
} 
models of enforcing equality law have been distinguished. ${ }^{61}$ The dualisms of individual justice and group justice as well as negative prohibition models and positive obligation models are best grouped under this perspective.

Relying on the extensive literature ${ }^{62}$ around these conceptual perspectives, a short summary of the main elements may suffice here. Formal equality is usually described as equality as consistency and aligned to an Aristotelian conception of equality, where the prerequisite for a claim to equality or equal treatment is being alike or comparable. This is captured by the sentence: Equals should be treated equally, and who is unequal should be treated differently in proportionate relation to their differences. Although this conception is deeply flawed, ${ }^{63}$ it does have the advantage of conveying a clear message: women and men are to be considered as fundamentally equal and unequal treatment requires a justification. As is apparent, this approach has been the basis for 'sameness feminism'. Substantive equality, as the opposing rationale, strives for equality through overcoming social disadvantage. As such, this approach may also be close to sameness feminism, depicting women and men in the future as indistinguishable individuals. This is where the dualism between individualistic and diversity models steps in: the individualistic model aims at gender differences becoming irrelevant to social reality, whereas the diversity model cherishes differences and strives to delimit or eliminate social inequality based on differences. Striving for substantive equality, effective enforcement becomes a problem for equality law. Again, the individual justice model of enforcement responds best to individual conceptions, whereas the group justice model is favoured by those supporting the diversity approach. The duality of negative prohibition and positive obligation is not conceptually keyed to equality law. It is rather to be considered as a response to new theories of governance in the area of equality law. A negative prohibition model would correspond to governance by command and control, whereas a positive obligation model is open for new ways of governance which are generally considered as more adequate responses to regulatory problems in an increasingly interrelated world.

As gender discrimination has been the focus of EU equality law, conceptions of equality have been discussed in relation to this ground at a European level. In jurisdictions other than the $\mathrm{EU}$, the academic discourse relates the same concepts to several equalities or to equality law in general. Accordingly, it is questionable whether the restriction to gender equality law in EU equality law is a necessary requirement. Nevertheless, different grounds of forbidden discrimination might also require different combinations of conceptions of equality. Conceptions of equality law might respond to a

\footnotetext{
61 See C. McCrudden, 'International and European Norms Regarding National Remedies for Racial Inequality' in S. Fredman (ed.), Discrimination and Human Rights (OUP, 2001), 251, 252.

62 Fredman, Discrimination Law; C. Barnard and B. Hepple, 'Substantive Equality' 59 Cam. L. J. 562 (2000); A. Numhauser-Henning (ed.), Legal Perspectives on Equal Treatment and Non-Discrimination (Kluwer, 2001).

63 See D. Schiek, 'Torn between arithmetic and substantive equality? Perspectives on Equality in German Labour Law', 18 Int. J. Comp. Labour L. Ind. Relations 149 (2002), 149-153.
} 
specific rationale for the more accepted grounds (such as gender in the EU context and 'race' in the UN context). Accordingly, acknowledging new grounds such as homosexuality, age and disability might rest on different rationales demanding different conceptions.

\section{Rationales for forbidding different grounds}

It is useful, for a first step, to consider the rational behind gender equality law. ${ }^{64}$ Gender equality undoubtedly is a very complex issue. It is at least partly about individuation, about becoming a unique human being by overcoming stereotypes one is deemed to follow. Its rationales include the diversity claim, maintaining that even though many women are capable of conceiving and bearing children, which men are unable to do, women should not be restricted to the domestic sphere; rather diverse public spheres should be adapted to the needs of those able to actively procreate the human race. Gender equality law is not necessarily aligned with a group identity. One could even deny that women do form a social group; ${ }^{65}$ although one could just as well consider women as a group suffering disadvantage, although each individual woman belongs to numerous other groups. ${ }^{66}$ The rationale of gender equality law is rather about anti-stereotyping and also about changing institutions, such as the family, which reproduce gender roles. ${ }^{67}$

Combating racial discrimination became a priority on the EU agenda following the increasing support for populist right-wing parties, in particular in the 1998 Austrian parliamentary elections, and preceding the challenge of enlargement. The impetus here was obviously that of proving the EU's capacity to maintain a civilised form of governance despite the insecurities brought about by enlargement. Mainly, one could conclude that the primacy of the fight against racism in human rights law was simply copied into EU equality law. Thus, the rationale of prohibiting racial discrimination

$64 \quad$ Recounting all the different approaches of feminist legal theory, evolving around problems such as gender and economic disadvantage, gender and violence and gender and domination, is beyond the scope of this (and possibly any) article. See on feminist legal thought from a US perspective, Chamallas, Feminist Legal Theory, 2003, K. Bartlett/ A. Harris/ D. Rhode, Gender and Law: Theory, Doctrine, Commentary, (Aspen, 2002). For European, Canadian and US views see K. Knop (ed) Gender and Human Rights (OUP, 2004). For European sociological debates see I. Rossilli (ed.), Gender Policies in the European Union, (Lang, 2000). For connecting feminist legal thought with specific perspectives on gender relations in Africa and Asia, see A. Stewart, Gender, Law and Social Justice, (Blackstone, 2000, reprint 2004).

65 D. Caruso, Limits of the Classical Method: Positive Action in the European Union after the New Equality Directives. Boston University, School of Law, Working paper No. 03-21, Boston 2003 (http:// www.bu.edu/law/faculty/papers/pdf_files/CarusoD090903.pdf).

66 See A. McColgan, Women under the Law. The False Promise of Human Rights, (Longman, 2000), 9. See also S. Fredman, 'The Age of Equality', in S. Fredman/ S. Spencer (eds.), Age as an Equality Issue (Hart Publishing 2003), 21, stating that, unlike race or gender, age does not define a discrete group, thus implying, that gender does define a discrete group.

67 See Bell, Anti-Discrimination Law, 43. 
would be similar to that of the UN convention serving the same aim. As stated in the title of CERD, its purpose is to eliminate all forms of racial discrimination, racial discrimination being defined as exclusion or disadvantage from the actual enjoyment of fundamental freedoms and human rights on grounds of race, colour, descent, or national or ethnic origin. Notwithstanding the narrower definition of racial discrimination in the Anti-racism Directive, ${ }^{68}$ the rationale behind the CERD can be considered to support that directive, especially as recital 3 of the Directive cites CERD. Rationales of prohibiting racial discrimination at international level have been manifold. They include individualisation, namely the aim of freeing man from being categorised according to outer appearances. However, CERD was also a reaction to the Holocaust and postcolonisation phenomena such as apartheid. ${ }^{69}$ Accordingly, the second rationale is that of protecting disadvantaged groups. $^{70}$

The issue of combating group disadvantage becomes more specifically one of preserving identity, if discrimination is not only prohibited in relation to race, but also in relation to ethnicity. Accordingly, the inclusion of 'ethnic origin' in the definition of discrimination under Directive 2000/43/EC, Article 2 has raised hopes of those pursuing minority rights. ${ }^{71}$ Protection against ethnic discrimination might rely on the rationale of recognising different identities, as conveyed by the 'politics of recognition'. ${ }^{72}$ Under this approach, that has also been labelled as static or integrationist communitarianism, ${ }^{73}$ equality law is to respect (that is, recognise) groups that are decisive for persons' identities. Under this view, groups are to be preserved, and group interests enjoy

68 For a critical comparison of that Directive and the General Policy Recommendation on National Legislation to Combat Racism and Racial Discrimination, adopted by ECRI, see E. Howard, 'Anti Race Discrimination Measures: An Attack on Two Fronts' 11 Eur. L. J. 468 (2005), 475-476 recounting the critique of the narrow conception of racial discrimination in Directive 2000/43/EC.

69 See K. Boyle/ A. Baldaccini, 'A Critical Evaluation of International Human Rights Approaches to Racism' in S. Fredman (ed.), Discrimination and Human Rights. The Case of Racism. (OUP, 2001), 141, 151.

70 This rationale becomes apparent from Articles 1 (4)and 2 (3) CERD, which provide for measures to overcome historic disadvantage of certain racial groups.

71 B. de Witte, 'The Constitutional Resources for an EU Minority Protection Policy', in G. Toggenburg (ed.), Minority Protection and the Enlarged European Union: The Way Forward, (Local Government and Public Reform Initiative 2004), 116-7. Hofmann and Friberg take a more critical approach, considering that Directive 200/43/EC is unable to fill lacunae for minority protection in Community Law (R. Hofmann/ E. Friberg, 'The Enlarged EU and the Council of Europe : Transfer of Standards and the Quest for Future Cooperation in Minority Protection', in Toggenburg (ed.), 136.

72 C. Taylor, 'The Politics of Recognition' in A. Gutman (ed.), Multiculturalism and the Politics of Recognition (Princeton University Press, 1992).

73 Other representatives of integrationist communitarianism are A. MacIntyre, After Virtue: A Study in Moral Theory (University of Notre Dam Press, 2nd ed. 1984); M. Sandel, Liberalism and the Limits of Justice (Cambridge University Press, 1982). On the distinction between different forms of communitarianism see Schiek, Differenzierte Gerechtigkeit, 41-43. 
considerable priority over individual interests. ${ }^{74}$ Even attempts at a liberal approach to multiculturalism ${ }^{75}$ have a tendency of allowing the aim of perseverance of a group (which is then capable of conveying collective identity) to dominate over issues of individual autonomy. ${ }^{76}$ Even if one endorses the more critical approaches towards a politic of recognition, it is questionable whether 'anti-discrimination law is tailor made for such politics' ${ }^{77}$ However, the argument that identity politics are a rationale behind protecting against discrimination on grounds of ethnicity (not necessarily ethnic origin) is convincing.

Identity is also at the heart of religious discrimination. In addition, in prohibiting religious discrimination, EU law also includes the rationale to protect the freedom to chose and profess one's religion, rendering the non-discrimination clause as an auxiliary to the substantive right of religious freedoms. The same point could be made in relation to sexual orientation, if human beings can choose their sexual orientation (and change it over time). The protection of this choice would be at the heart of a prohibition of discrimination on grounds of sexual orientation.

Gender, race and ethnicity as well as religion have been characterised as established categories of human rights that posed specific difficulties for acceding Member States to adapt. ${ }^{78}$ Disability, age, and sexual orientation, while being increasingly recognised as important issues of equality law on the international level, ${ }^{79}$ lack this aura of broader acknowledgement. Those social formations have been attributed the characteristic of being a 'new generation of civil and social rights' that 'should be developed in the course of modernizing and restructuring the way in which European welfare states regulate life courses and family arrangements of their citizens. ${ }^{80}$

$74 \quad$ A case law example which illustrates this danger quite well is the US Supreme Court decision on the question of whether the Amish are allowed to bar their children from public school education after the eighth grade, lest they would never acquire the ability to become either a farmer or a housewife under the conditions typical for the Amish lifestyle and the desire to strive for nothing else (406 U:S. 205 (1972), 211; criticized e.g. by W. Kymlicka, 'Individual and Community Rights' in J. Baker (ed.), Group Rights, (University of Toronto Press, 1994), 19.

75 See W. Kymlicka, 'Liberal Theories of Multiculturalism', in L. Meyer et al. (eds.), Rights, Culture and the Law. Themes from the Legal and Political Theory of Joseph Raz, (OUP, 2003).

76 See Y. Tamir, 'Against Collective Rights', in Meyer, Rights, Culture and the Law, 187-8, referring to the preservation of a French community in Canada requiring the imposition of the choice of French as a language on citizens living in certain environments.

77 McCrudden, New concepts of equality, 2003, 16.

78 Mabbet, 'The Development of Rights-based Social Policy in the European Union: The Example of Disability Rights', 106.

79 D.Buss et al., 'Introduction to Sexual Movements and Gendered Boundaries: Legal Negotiations of the Global and the Local' 14 Social \& Legal Studies 1 (2005), 1, with numerous references for sexual orientation.

80 Mabbett, 'The Development of Rights -based Social Policy in the European Union: The Example of Disability Rights', 106. 
This inclusion is probably a little overbroad. Protecting against discrimination on grounds of sexual orientation is certainly linked to the way in which family arrangements and life courses are chosen, if one considers sexual orientation as a matter of choice, and subject to changes over time. However, this approach is not shared by all gay and lesbian rights activists. In fact, here lies a hidden dispute on rationales for lesbian and gay rights. Striving for a true choice of sexual orientation and life style in regard to family arrangements is closely linked to a feminist vision of combating gender discrimination. ${ }^{81}$ As stated earlier, in this view, combating gender discrimination is about dissolving institutions which reproduce gender role expectations, granting individuals the freedom to choose how they wish to live irrespective of their ascribed gender. Choosing a same sex partner (for a while) would aim at institutional escape from the expectation of heteronormativity. What has been labelled a libertarian approach to gay rights above, would usually rest on a different conception of sexual orientation, viewing it as a given strand of one's identity. ${ }^{82}$ In this line, sexual orientation has been characterised as one of the forbidden grounds most explicitly incorporating the vision of equality as recognition of difference. $^{83}$

As regards disability and age, these grounds cannot be perceived as a matter of choice. Age is experienced by each of us, changing every minute, and always in the same direction. Disability can be defined in two different ways. A static definition focuses on the person in question, considering whether she has an impairment that permanently diminishes a capability to participate in social life. A dynamic definition focuses on the interaction of society with individuals and is able to detect structural exclusion as the reason for people being disabled, depicting disability as a result of interaction of social constraints with specific individual abilities that happen to be different from what is expected. ${ }^{84}$ Modern definitions of disability as adopted by the UN standards Rules on Disability and the World Health Organisation's International Classification of Impairments, Disabilities and Handicaps, integrate both approaches: They do acknowledge that disabled persons suffer from impairments, which develop into handicaps in interaction

On the link between sexuality rights and feminism see below note 94 .

82 See INITIAL Rollins, 'Same Sex Unions and the Spectacles of Recognition', 39 Law \& Society Review 457 (2005).

83 McCrudden, New concepts of equality, 2003, 16.

84 A German slogan of the disability movement, that is beyond translation, captures this model: 'Behindert ist man nicht, behindert wird man': No-one is disabled (using the verb 'to be' in a static sense, as in the Spanish word 'ser'), but some people are made disabled (using the verb to be as an auxiliary verb for the passive voice). In the British discussion, this model is referred to as 'social model of disability'; see M. Oliver, 'If I had a hammer: the social model in action' in J. Swain et al., Disabling Barriers - Enabling Environments, (SAGE, 2nd ed. 2004), 7-12. 
with disabling social institutions. ${ }^{85}$ As disability, age goes along with bodily change, leading to all kinds of impairments. However, both age and disability are also concepts subject to social construction and false stereotyping. ${ }^{86}$ Accordingly, age and disability can be considered as similar, ${ }^{87}$ although the latter does not affect everybody, in contrast to the former. Both grounds for forbidden discrimination require recognition of difference, although few people would consider age as an identity question. ${ }^{88}$ In addition, both grounds force lawyers to recognise that grounds of forbidden discrimination do not always come neatly packed as dualities. While some still consider that a person is 'either male or female or a native or an immigrant' ${ }^{89}$ with disability there is no denying the fact that this terms summarizes multiple identities, such as being blind, deaf, mentally impaired or having lost one's legs. ${ }^{90}$ This makes it impossible to consider the disabled as one group. ${ }^{91}$ Similarly, age is a diverse category, and discrimination against young and old people differs widely. ${ }^{92}$ As regards age, in addition to the rationales cited above, the rationale of providing dignity and autonomy respecting different abilities are stressed. ${ }^{93}$ The same rationale supports a prohibition of disability discrimination.

In sum, there are different rationales for prohibiting discrimination, and these may also differ across grounds of forbidden discrimination.

Gender as a ground for forbidden discrimination has the rationale of enabling persons to choose the life they wish irrespective of gender stereotypes (individuation), but also rests on a rational of group justice if one considers distribution of resources between the 'groups' of women and men. If one considers sexual orientation as a matter of choice for human beings, the rationale of individuation applies to this forbidden

85 See. Thomas, 'Disability Theory: Key ideas, issues and thinkers', in C. Barnes et al. (eds.), Disability Studies Today, (Polity Press, 2002), 41-46; K. Inghammar, 'Discrimination of People with Disabilities' in INITIAL Numhauser-Henning (ed.), Legal Perspectives on Equal Treatment and Discrimination (Kluwer, 2001), 324.

86 On age, G. Evans, 'Age Discrimination: Implications of the Ageing Process' in S. Fredman/ S. Spencer (eds.), Age as an Equality Issue, 16-19.

87 M. Sargeant, 'Disability and age - multiple potential for discrimination' 33 International Journal of the Sociology of Law 17 (2005), 19.

88 However, there are those who consider disability as an identity question, e.g. D. Pothier, 'Connecting Grounds of Discrimination to Real People's Real Experiences' 13 Canadian Journal of Women and Law 37 (2001), 72.

89 Inghammar, 'Discrimination of People with Disabilities', 326. Baroness Hale in Archibald v Fife Council, stating that 'men and women, black and white are the opposite sides of the same coin' [2004] IRLR 651.

90 Inghammar, 'Discrimination of People with Disabilities', Of course, gender and ethnicity are just as diverse. The normative assumption that you are 'either male or female' denies the reality of transgendered persons who do not fit neatly into these categories, and with ethnicities it is rather self evident that there are more categories than 'immigrant' and 'native'.

91 Inghammar, 'Discrimination of People with Disabilities'.

92 See Fredman, 'The Age of Equality', 24, conceding that there may even be conflicting interests of the young and the old.

93 See Fredman, 'The Age of Equality', 41-45; Sargeant, 'Disability and age - multiple potential for discrimination', 32, stressing individual dignity. 
ground as well, rendering the boundaries between gender and sexual discrimination flexible. ${ }^{94}$ Prohibiting racial discrimination also rests on a rationale to overcome stereotyped expectations as a determinant of life.

However, in prohibiting discrimination on grounds of race and ethnicity, identity politics emerges as an alternative or additive rationale for anti-discrimination law. This rationale can only partly be pursued by equal treatment as it requires collective rights of recognition in addition. Identity might also be a rationale for prohibiting religious discrimination as might be the desire to back up protection of religious freedom with a prohibition of discrimination. The same combination of rationales would support a prohibition of discrimination on grounds of sexual orientation if one does consider this to be a matter of choice. Additionally, choosing one's sexual orientation is an aspect of individuation.

Regarding age and disability, anti-discrimination norms rest on the rationale of allowing autonomy and dignity irrespective of bodily difference. The same rationale also applies to discrimination on grounds of sex, as opposed to gender discrimination, where issues of pregnancy and motherhood need to be integrated by respecting diversity between women and men.

\section{Rationales and conceptions}

Do these different rationales for different grounds necessarily require diverse conceptions of equality law? Or is it conceivable to conceptualise equality law in a way that integrates all of them? Obviously, there are different approaches to this.

Some authors caution against the wide expertise in gender equality law becoming too important for EU anti-discrimination law. These authors demand that concepts developed in gender equality law should not be transposed to other (in)equalities. ${ }^{95}$ This claim corresponds with the position that new concepts, related to the new rationale of identity, are specific to the new grounds. ${ }^{96}$ Possibly, the policy of the EU to draw a sharp line between pursuing gender equality on the one hand and the other equalities on

94 The possibility even exists to classify discrimination on grounds of not choosing the dominant heterosexual life-style as discrimination on grounds of a moral commitment to gender equality; see D. Richards, Identity and the case for gay rights: race, gender and religion as analogies (The University of Chicago Press, 1999), especially 193-196. It seems, however, odd that only gays and lesbians should be accepted as deviating from dominant heterosexual lifestyles and not, e.g., those denying a stable heterosexual partnership on other grounds or those choosing a role model within a heterosexual life style that deviates from the dominant norm.

95 C. McCrudden, 'Thinking about the discrimination directives' 1 Eur. Anti-Discrimination L. Rev. 17 (2005), 17.

96 McCrudden, New Concepts of Equality, 2003. 
the other hand ${ }^{97}$ rests on this desire to render expertise gained in gender equality issues irrelevant to the other equalities.

It may well be the case that different rationales require different conceptions. It is questionable, though, whether the differences are ground specific. Gender equality in particular rests on the politics of individuation as well as the politics of difference. Coming back to the three-fold categorical divisions of human inequalities developed elsewhere, ${ }^{98}$ I would propose pursuing conceptions responding to ascribed otherness, traits resulting in bodily difference and traits resulting from personal choice. However, these categories cannot be distinguished clearly in all cases. For example, in the case of gender, this is an ascribed category insofar as role expectations are linked to the perception of a person as female or male, but also a category of bodily difference. Last but not least, gender as a social concept is also a matter of choice, as persons are able to choose not to follow a traditional gender role model, inter alia by opting for a lifestyle different from the norms imposed on heterosexual couples. Similarly, prohibiting racial and ethnic discrimination rests on rationales of individuation and preserving of identity at the same time.

The difference in conceptions of equality per each ground does not seem as striking as it is depicted at times. Comparing the sections on 'conceptions of equality' written by Sandra Fredman in general, ${ }^{99}$ in the context of race ${ }^{100}$ and age, ${ }^{101}$ the reader perceives striking similarities. In either case, the starting point for deliberation is equality as consistency, which is characterised as insufficient, though valuable. ${ }^{102}$ This is followed by equality of results, equality of opportunity and equality as a value driven approach. ${ }^{103}$ The issues stressed under the heading 'value driven approach'104 are specified for age discrimination. Here, autonomy and dignity are stressed more strongly than in general. ${ }^{105}$ Additional issues raised in relation to age are 'each according to their needs'

$97 \quad$ As is witnessed by placing the responsibility for these two strands of equality law in the hands of different subdivisions of the relevant Directorate General and also by the fact that the conference from which this special issue sprang took place one day after a conference on all the other grounds, in which gender was not a strand of discussion.

98 On the distinction between ascribed and chosen characteristics and different needs for protection against discrimination in the market place (to be distinguished from constitutional equality law), see Schiek, 'A New Framework of Equal Treatment of Persons in EC Law', 308, and - more expanded - Schiek, Differenzierte Gerechtigkeit, 25-38.

99 Fredman, Discrimination Law, 1-26.

100 Fredman, 'Combating Racism with Human Rights: The Right to Equality', in Fredman (ed), Discrimination and Human Rights, 9-44.

101 Fredman in Fredman/ Spencer (eds.), Age as an Equality Issue, 21-69.

102 Fredman Discrimination Law, 7-11; Fredman 'Equality: A New Generation?' 16-18, and Fredman 'The Age of Equality',38-9.

103 See Fredman Discrimination Law, 11-23; Fredman 'Equality: A New Generation?', 19-22.

104 Dignity, remedial and restitutory aims, distributive justice and participation, see Fredman, Discrimination Law, 15-22.

105 See Fredman 'The Age of Equality', 43-45. 
Dagmar Schiek

and 'fair distribution'. This recount is not meant to diminish the accomplishments of one of Europe's most renounced theoreticians on equality law. Its purpose is rather to demonstrate that conceptions of equality are coloured by different rationales, while not being fundamentally diverse per ground.

As a tentative conclusion, an acknowledgment that each ground of forbidden discrimination forces us to focus on different conceptions of equality is proposed, which leads to the conclusion that equality law is enriched when different grounds are included. However, there is probably no clear link between different grounds and different conceptions in the sense that some conceptions are adequate to some grounds and not to others.

\section{Conflicting rationales and separated spheres of equality}

Naturally, there is the possibility of conflict between these different rationales for single grounds.

Some examples may suffice to illustrate that this is another huge theme. For example, gay rights activists from a libertarian perspective might argue that prohibiting discrimination on grounds of sexual orientation would require the opening up of the institution of marriage to all people. From a gender perspective, marriage as such could be depicted as an institution of subordination that should lose relevance, rather than gaining it, in order to further individuation of women. ${ }^{106}$ Another example has been given referring to the difference of gender and ethnicity on the one hand and disability on the other: presumably, in regard to the former, equal treatment in a formal and symmetric sense is enough, while the latter requires a more substantive approach, submitting employers to a duty to accommodate difference. ${ }^{107}$ The list of conflicts could be extended at ultimo. The purpose of this section being whether an additive approach is capable of resolving such conflicts, it may be sufficient to focus on one of the possible issues. The issue chosen is the possible tension between the rationale of preserving group identity and the rationales underlying gender equality. This focus was partly spurred by a specific article on the 'new equalities'.

In a 2003 article, Caruso ${ }^{108}$ discusses whether the ECJ should reconsider its case law on positive action now that EU equality law addresses more grounds than gender. Instead of offering a critique of the merely formalist approach of the ECJ towards equality law, she proposes a new categorisation of different equalities, labelling race, ethnicity and

106 See Rollins, 'Same Sex Unions and the Spectacles of Recognition'.

107 Baroness Hale, in Archibald v Fife Council, stating that 'men and women, black and white' are the opposite sides of the same coin [2004] IRLR 651.

108 Caruso, 'Limits of the Classical Method: Positive Action in the European Union after the New Equality Directives' (2003) Boston University School of Law Working Paper 03/21, (http://www.bu.edu/law/ faculty/papers/pdf_files/CarusoD090903.pdf) 
religion as 'meaningful categories of identity', while considering that women are 'neither a minority nor a group'. This last statement corresponds to the European Parliament's reasoning in widening the scope of application of gender equality law in the proposal for Directive 2004/113/EC. ${ }^{109}$ In Caruso's view, gender not being an identity category means that it looses its relevance among the new grounds. Identity politics are, in her view, at the heart of the vision of multiculturalism, which again feeds the new anti-discrimination policy. To persist as a meaningful category, identity seems to require that those sharing the identity are a minority group: she depicts identity politics as politics for preserving groups in danger of being suppressed.

This form of identity politics does seem to underlie much of the 'new equalities' policy. If we analyse the Commission's Green Paper on Equality and non-discrimination in an enlarged European Union, ${ }^{110}$ different groups, which are in need of protection, are mentioned frequently, as is the need to include minorities and disadvantaged groups. ${ }^{111}$ The imagery of protecting identity by group preservation is based on the assumption that individuals build their identity around belonging to a certain group or constituency. Equality law, if it follows this logic, becomes a body of rules aimed at balancing the social relations between these groups. This conjures up an image of independent villages, the inhabitants of which just happen to have different customs. While these villages are allocated equal resources, the inhabitants are not considered as individuals that might wish to move between the villages or even found new ones or lead an nomadic life altogether. ${ }^{112}$

Identity politics in this rather conservative sense, with its primary purpose of preserving independent groups, might prove rather problematic from a gender perspective. The gender issue will inevitably arise in each of these autonomous communities, as a community closed off to others will need both sexes for their continued existence. Accordingly, closed off communities need to claim women (and

109 European Parliament Report on the proposal for a Council Directive implementing the principle of equal treatment between women and men in the access to and supply of goods and services, A5-0155/ 2004 final.

110 Commission of the European Communities, Equality and Discrimination in an Enlarged European Union (Brussels 2004), this Green Paper has been followed by a Commission communication on Nondiscrimination and equal opportunities for all. A framework strategy COM 2005 (224).

111 Equality and Discrimination in an Enlarged European Union (2004), 10, 19.

112 There are ways for the legal mind to evade this dilemma, as is demonstrated by the Canadian Supreme Court decision in Corbiere v. Canada (Minister of Indian and Northern Affairs) [1999] 2 S.C.R. 203. First nation Canadians who were not living on a reservation were denied voting rights for band leadership. Here, those who did move from 'their' community but still wished to retain a bond were not acknowledged by law. Instead of insisting on an absolute definition of being a First nation Canadian, the Court accepted that those First nation Canadians living away from reservations were a specific group worthy of protection under Canadian law. The Canadian Supreme Court addressed the dilemma of group pressure against those wishing to leave by acknowledging that those having chosen a life outside the reservation formed a distinct entity. This is only a first step towards acknowledging fluid identities, but it shows that there are ways of solving the dilemma. 
men) as belonging, possibly restricting their mobility and requiring them to respond to identity specific gender images. ${ }^{113}$

Under a conservative approach to group identity, the role of women may be considered decisive for the identity of a group. The problematic premises of this may be illustrated by the law's response to the issue of headscarves. If Muslim women are subjected to pressure if they wear a headscarf in public, the question arises whether they may raise a discrimination claim. Obviously, the requirement to wear a headscarf is only accepted by or imposed on [certain?] women. If women are considered symbols of collective identity, Western people may claim that any woman wearing a headscarf is a danger to their identity, and Muslim people may claim that banning headscarves for women (or allowing them to take them off) endangers their collective identity. For the women affected on both sides the sentence 'embeddedness in a community may mean being stuck ${ }^{114}$ may feel like a lead weight.

The group identity rationale obviously conflicts with the individuation rationale that has been analysed as supporting gender equality. Under this rationale, women need to be accorded the right of not responding to community demands to adapt to their standards of identity politics. Accordingly, Western women should not be required to wear skirts an imposition that has, in the UK, effectively been removed by the insistence of Muslim women on wearing trousers, ${ }^{115}$ while Western women refusing to wear skirts have been less successful ${ }^{116}$, but equally they should not be prevented from doing so. In the same line, Muslim women should not be required to adapt to Western styles of female identity, but certainly they should not be forced to retain the attire of femaleness required by some conservative factions of their community.

Under an additive approach to equalities, the resolution of such conflicts is contingent on hierarchies between equalities. For example, the proposal has been made to require communities to remain in a process of dialogue rather than cherishing communal identity as an aim in itself. ${ }^{117}$ This proposition prioritises communities - i.e. the group

113 Nicola Lacey makes a similar point by stressing the oppressive potential of group rights in relation to fixing identities generally. See N. Lacey, 'Feminist Legal Theory and the Rights of Women', in: Knop (ed.), Gender and Human Rights, 49.

114 M. Galenkamp, Individualism versus collectivism. The concept of collective rights. (Gouda Quint, 1998) 139.

115 Malik v. Bertram Personnel Group [1991] 7 EOR 5: If a Muslim woman is prohibited from wearing trousers under the employer's uniform, this may qualify as indirect race discrimination. The same issue was raised by a Sikh woman in Kingston \& Richmond, AHA v. Kaur [2000] 1 ALL ER 857.

116 Schmidt $v$ Austicks Book Shop Ltd 1977 [IRLR] 360.

117 'The (...) supporters of multiculturalism must (...) avoid the transformation of "multi-culturalism" into "multi-communitarianism" (citation omitted). Whilst a multicultural society is indeed tolerant towards cultural differences, open to negotiation and capable of favouring exchange between cultures (while also maintaining the right to disassociate from a particular culture), a multi-community society sees cultural difference as a value in itself, denying the possibility of an exchange between cultures. This produces communities as fortresses, not open to negotiation, and closed off from communication.' D. Lyon \& D. Spini, 'Unveiling the Headscarf Debate' 12 Feminist Legal Studies 333 (2004), 340. 
Broadening the Scope and the Norms of EU Gender Equality Law: Towards a

Multidimensional Conception of Equality Law

identity rationale - over the individuals within the groups - i.e. the individuation rationale - transforming other grounds, such as gender, into items for negotiating cultural identity. An additive approach frames hierarchy of equality aspects. Thus, theoretically, gender could be made the priority. With reference to the headscarf issue, this would require prioritizing the aspect of gender. Consequently, women's choices would prevail over perceived requirements of communities. If EU equality law was to adopt an additive approach, it would have to develop a mode for deciding on priorities of grounds in cases of conflicting rationales.

\section{Advantages and dangers of retaining an additive approach to equality law}

To recap, what are the advantages and dangers of an additive approach to equality, or rather, equalities law? Finding that different grounds of forbidden discrimination focus on different rationales, we have discovered that, in order to engender equality irrespective of most grounds, we need to follow diverse rationales. Accordingly, the quest for a connection of rationales and conceptions for equality led us to conclude that multifaceted equality law prompts lawyers to integrate different conceptions. The issue of different rationales also led to the question of how to reconcile conflicts, an issue which cannot be resolved under an additive approach. Focusing on single grounds has the advantage of exposing different rationales and their connection to conceptions more clearly than an attempt to focus on all grounds at once. The interrelation of different conceptions and rationales in most grounds, however, implies that retaining single strands of equality law is less advantageous than striving for an integrated approach.

\section{MULTIPLYING OF GROUNDS: ISSUES OF AN INTEGRATED APPROACH TO EQUALITY LAW}

We now address some issues of an integrated approach. ${ }^{118}$ After taking up the issue of reconciliation of different equalities, the potential of equality law to address the multifaceted reality of human beings will be addressed. The latter issue, also discussed under the notion of intersectionality, will be analysed in a comparative manner.

\section{Reconciling different equalities}

While an additive approach does not offer much in terms of reconciling different equalities, this is considered as one of the strengths of an integrated approach.

Returning to the headscarf example, an integrated approach would require the negotiation of neither ethnic identities nor gender, but rather the reconciliation of different rationales. As explained, group identity preservation competes with individua-

118 See on the notion of an integrated approach, note 59. 
tion irrespective of gender norms in this example. Reconciling these rationales would imply an acknowledgement that individuals should be free to move in and out of communities. Individuation requires freeing individuals from the request to conform to collective identity standards and enabling them to leave an overly oppressive group altogether. The rationale of recognition of identities requires Western people to refrain from focusing exclusively on outer appearance codes imposed on non-Western women, ${ }^{119}$ but to reflect on Western codes for accepted femininity, such as shaving one's legs, undergoing breast surgery or wearing high-heels. Negotiating identities would then take on a more egalitarian inter-ethnic notion, making it impossible to outlaw femininity codes of only selected communities.

As much as an integrated approach would have to offer in reconciling different rationales, these reconciliations will always have their limits. In engaging in this kind of reconciliation, an integrative approach also risks diluting those grounds that are more likely than others to contribute to social disadvantage and exclusion and thus lose focus. ${ }^{120}$ Accordingly, the exercise of reconciliation would have to include reconciling an integrated approach with logics of single grounds, but this is an issue beyond the scope of this article.

\section{Multifaceted human reality - intersections of grounds}

Analysing how discrimination is affected by multifaceted human reality, critical discourses on equality law have coined the terms multiple and intersectional discrimination. Multiple discrimination is characterised as an experience of added discrimination, for example as a woman and a person to whom ethnic minority status is ascribed, whereas intersectional discrimination is discrimination experienced by persons on grounds of being representative of intersectional characteristics, for example as a black woman. ${ }^{121}$ Human beings cannot be disaggregated into single components, such as being

119 Cooper convincingly argues that 'gendered minority practice receive a level of critical attention out of all proportion to their pervasiveness and influence' and proposes 'to look away from that which stands out as different in order to be able to evaluate the mainstream'; D. Cooper, Challenging Diversity, 193-4.

120 This point is made by several authors. Cooper for example, mentions the danger of 'hypersectionality' making it 'impossible to talk about race, class, age and gender altogether since, if they are always enmeshed, how can we ever know what each of these (...) contribute?', Challenging Diversity, 49. Holzleithner warns against the danger that 'the intersectional approach should (...) keep us from analysing the specific workings of singular power vectors', E. Holzleithner, 'Faces of Discrimination: The Case of Sex Equality', in Cormack (ed.), Protection against Discrimination and Gender Equality - how to meet both requirements, Brussels 2003, 5. Pothier submits that single grounds such as gender and race 'are an important means of providing the necessary history and context of discrimination', 'Connecting Grounds of Discrimination to Real People's Real Experiences' in 13 Canadian Journal of Women \& Law 37 (2001), 40 and stresses that 'grounds also identify important elements of individuality, 72.

121 K. Crenshaw, 'Demarginalizing the Intersection of Race and Sex: A Black Feminist Critique of Antidiscrimination Doctrine, Feminist Theory and Antiracist Policies', University of Chicago Legal Forum 139 (1989) (cited from the reprint in D.K. Weisberg (ed.), Feminist Legal Theory: Foundations (Temple, 1993), 383, 385). 
female, black, heterosexual and atheist, to name just some examples. Consequently, intersectional discrimination is generally considered as the more common form in which discrimination occurs. ${ }^{122}$ Under the perspective of integrating several forbidden grounds into a coherent framework of equality law, the adequate response to intersectional discrimination is one of the decisive questions.

\section{(a) Restricted approaches: the Anglo-American Legacy}

EU equality law is often depicted as based on Anglo-American concepts of equality law. ${ }^{123}$ If this is so, it is rather troubling for EU equality law that equality law in the United Kingdom as well as in the US has been accused of not being able to adequately respond to multiple and intersectional discrimination. ${ }^{124}$

These alleged problems seem to emanate from a narrow reading of each single prohibition of discrimination, which is especially prominent in court cases. For example, in the US, the Ninth Circuit Ccourt did not accept black women as a specially protected group, and the claim of disparate impact discrimination failed for this reason. ${ }^{125}$ The decision turned on the statistical element of disparate impact. The claimants could show that selecting personnel for dismissal worked to the detriment of black women, while its effects were balanced in terms of gender and racial equality considered individually. The court did not even allow them to proceed to the next stage, at which the employer would have been required to bring forward objective reasons justifying the disparate impact. The possibility of considering disparate impact and thus indirect discrimination against black women was disregarded. An example cited in UK writing is a case in which a black woman raised a claim of racial and sex discrimination when she was excluded from the procedure for applying as special supervisor to the Lord Chancellor. ${ }^{126}$ The Lord Chancellor chose to include only persons known to him personally in the pool of possible applicants. These persons were mainly male and considered white. The courts failed to acknowledge this as an unlawful case of indirect discrimination, considering that being

122 T. Makkonen, Multiple, Compound and Intersectional Discrimination: Bringing the Experiences of the Most Marginalised to the Fore (Abo Akademi University, 2002) (http://www.abo.fi/instut/imr/norfa/timo.pdf), 9-16 with numerous references.

123 Nielsen, Gender Equality, 25; Bell, Anti-Discrimination Law, 187, considering that the Netherlands and Ireland also qualify as model jurisdictions on which to draw for EU equality law. For legislation combating discrimination against people with disability, St. Grammenos, Illness, disability and social inclusion, (European Foundation for the Improvement of Working and Living Conditions, 2003) available at http://www.eurofound.eu.int/publications/files/EF0335EN.pdf), 61-72.

124 Crenshaw, University of Chicago Legal Forum (1989), 139-167; D. Ashiagbor, 'The intersection between Gender and Race in the Labour Market: Consequences for Anti-Discrimination Law', in A. Morris/ Th. O'Donnel (eds.), Feminist Perspectives on Employment Law, (Cavendish, 1999); S. Hannett, 'Equality at the Intersections: The Legislative and Judicial Failure to Tackle Multiple Discrimination' 23 O. J. L. S. 65 (2003), 67, each with further references.

125 Moores $v$ Hughes Helicopter Inc, 708 F.2d 475, 480 (9th Cir 1983).

126 CA/2001/0294, 2001 IRLR 116. 
known to the Lord Chancellor prior to employment was an objective qualification for this specific job and any disparate impact of applying this selection criterion thus justified. The case was only decided in relation to sex discrimination, not to intersectional or race discrimination. These examples, among many, show some practical problems with retaining single strands of equalities within an additive approach.

On a more conceptual level, Ashgiabor criticises the fact that many of the leading cases on indirect gender discrimination deal with disadvantages for part time workers. She finds that restricting oneself to part time employment in order to be able to take the main responsibility for raising children while relying on the earnings of a male partner is a pattern found mostly among women considered as white in Britain. Accordingly, the statistical merger of the majority of white women and the minority of those considering themselves as ethnic minority women tends to neglect the social reality of the latter category. Taking this analysis a step further, it might be more appropriate to consider discrimination against part timer workers as discrimination against ethnic majority women in certain national contexts instead of indirect discrimination against all women. ${ }^{127}$

There are, however, counterexamples of how US and UK courts have acknowledged multiple or intersectional discrimination. First cautious steps towards this were taken by US courts, including the Supreme Court. These courts have developed a special category of 'sex plus cases' to consider direct discrimination against certain classes of women as illegal, although it was not directed against all women. ${ }^{128}$ Accordingly, subjecting all black women to a disadvantage could be considered sex discrimination, although white women were not affected. ${ }^{129}$ However, under this rather cautious approach, those considering themselves discriminated against still have to decide which ground is the primary reason for discrimination. ${ }^{130}$ Occasionally, courts have acknowledged the specific characteristic of intersectionality claims. Wei cites a Ninth Circuit decision upon a claim of an Asian woman applying for the position of Director of the University of Hawaii Law School's Pacific Asian Legal Studies Programme. ${ }^{131}$ The university had twice invited applications for this position, but did not employ anyone. The process resulting in the decisions to not fill the position had been flawed by a number of procedural shortcomings. While the District court concluded, from the fact that offers had been made to an Asian man and a white women, that both gender and racial discrimination

127 Ashiagbor, 'The intersection between Gender and Race in the Labour Market: Consequences for AntiDiscrimination Law', 143-146.

128 Phillips v Martin Marietta Corp., 400 US 542 (1971).

129 Jefferies $v$ Harris County Community Action Association 615 F 2d 1025 (5th Circ).

130 Scarborough 'Conceptualizing Black Women's Employment Experiences' 98 Yale Law Journal 1457 (1989), 1471.

13140 F3d 1551, 1562 (9th Cir. 1994); see V. Wei, 'Asian Women and Employment Discrimination: Using Intersectionality Theory to Address Title VII Claims based on Combining Factors of Race, Gender and National Origin' 37 Boston College Law Review 771 (1996), 783-785. 
could not be upheld, the Circuit court considered that it was inadequate to analyse the University's conduct for separate biases based on race and gender, as there are specific stereotypes operating to the detriment of Asian women. The case was not decided on the facts, though, but redirected to the district court. The claimant dropped her claim in the ensuing proceedings. From the UK, Hannet reports an Employment Tribunal decision which accepted adverse treatment for wearing a headscarf as discrimination on the basis of both race and sex, criticising the Tribunal for only applying an additive approach. ${ }^{132}$

Partly as a policy response to this critique (though no direct reference occurs), the single issue approach to equality legislation is in the process of being reconsidered in the UK. On the occasion of implementing the Anti-racism and the Framework directive, government advisers have come forward with proposals to merge the three pieces of legislation into a Single Equality Act or, at least, to establish just one single equality body instead of a Commission for Racial Equality, an Equal Opportunity Commission and a Disability Rights Commission. ${ }^{133}$

\section{(b) A more integrated approach? Canadian Law}

Intersectional discrimination has been one of the main discussion topics in Canadian equality law for a long time, leading inter alia to an explicit acknowledgement in the text (rather than the recitals) of the Canadian Human Rights Act. ${ }^{134}$ The discussion preceding its adoption has been portrayed as focusing on a new conception of identities. ${ }^{135}$ Instead of conceiving of discrimination as being directed against some monistic identity, such as homosexuality, femaleness, blackness or being disabled, equality law theory accepted the flexible and overlapping character of identities. Case law on intersectional discrimination has developed under the Canadian Charter of Human Rights, which, as is well known, provides in section 15 for what has been characterised as a substantive equality clause,

132 Hannett, 'Equality at the Intersections: The Legislative and Judicial Failure to Tackle Multiple Discrimination', 79.

133 Notably in the UK, the feasibility of a single equality act and single equality legislation has been discussed widely; see B. Hepple/ M. Coussey/ T. Choudhoury, Equality: A New Framework. Report of the Independent Review of the Enforcement of UK Anti-Discrimination Legislation (Hart, 2000), para 2.62; C. O'Cinneide, A Single Equality Body: Lessons from abroad, (Equal Opportunities Commission, Working Paper Series No. 4, 2002).

134 Section 3.1. was amended in 1998 to the following:

For greater certainty, a discriminatory practice includes a practice based on one or more prohibited grounds of discrimination or on the effect of a combination of prohibited grounds.

(Canadian Human Rights Act, S.C. 1998, c. 9 s. 11)

135 E. Grabham, 'Law v Canada: New Directions for Equality under the Canadian Charter?' 22 O. J. L. S. 641(2002), 649. 
focusing on disadvantage rather than on differentiation. ${ }^{136}$ The Charter's Equality clause is open ended, enumerating a list of examples for grounds of forbidden discrimination. In contrast to this, the UK Human Rights Act contains a closed list of forbidden grounds.

Canadian discussions on how the law should adequately respond to intersectional discrimination ${ }^{137}$ started with a reference to Crenshaw's conceptions. ${ }^{138}$ At this time, the Supreme Court had already acknowledged that Canadian equality law does not require a particular single ground being the only reason for discriminatory behaviour. ${ }^{139}$ This parallel to the 'sex-plus' case law of the U.S. Supreme Court did not automatically entail that Canadian equality law would truly incorporate intersectionality. For example, in a case before the Canadian Human Rights Commission, the claim of an Ojibway woman for being made redundant on alleged incompetence, combining issues such as sexual harassment and discriminatory dismissal based on sex and race, failed before the Federal Court. ${ }^{140}$ Under the Canadian Charter with its open-ended list of grounds, the discussion developed along the lines of whether intersectional categories should be accepted as 'analogous grounds' that are not contained in the open-ended list but are of equal concern to equality law. This discussion is bound up with the question of whether it is wise to retain the relevance of grounds or whether one should focus on discriminatory behaviour without such reference. ${ }^{141}$ However, the Supreme Court did refer to combined grounds in acknowledging them as analogous. For example, in Corbière, ${ }^{142}$ the question was whether First Nation Canadians who did not live on an assigned reservation could challenge an act excluding them from the vote for band leadership. The question of whether the category of band members not living on the reservation would qualify as an

\footnotetext{
136 This provision reads:

(1) Every individual is equal before and under the law and has the right to the equal protection and equal benefit of the law without discrimination, and in particular without discrimination based on race, national or ethnic origin, colour, religion or sex, age or mental or physical disability.

(2) Subsection 1 does not preclude any law, program or activity that has as its object the amelioration of conditions of disadvantaged individuals or groups including those that are disadvantaged because of race, national or ethnic origin, colour, religion or sex, age or mental or physical disability.

137 It is rather impossible to give a complete overview of the vast discussion. Over and above Grabham, 'Law v Canada: New Directions for Equality under the Canadian Charter?', the following report is based on Pothier, 'Connecting Grounds of Discrimination to Real People's Real Experiences', and N. Duclos, 'Disappearing Women: Racial Minority Women in Human Rights Cases' 6 Canadian Journal of Women \& Law 25 (1993).

138 Duclos, 'Disappearing Women: Racial Minority Women in Human Rights Cases'.

139 Janzen $v$ Platy Enterprises Ltd [1989] 1 SCR 1252: Sexual harassment was acknowledged as sexual discrimination although not all women were subjected to it.

140 Canada (Attorny General) v. Canadian Human Rights Commission (1991), 43 F.T.R. 47.

141 A. Bayefsky, 'A Case Comment on the First Three Equality Rights Cases under the Canadian Charter of Rights and Freedoms' (1990) 1 Supreme Court Law Review (2d) 503 (518-521). Justice L'Jheureux-Dubé in Egan $v$ Canada [1995] 2 SCR 513 at 551-2 ('By looking on the grounds for the distinction instead of at the impact of the distinction on particular groups we risk undertaking an analysis that is distanced and desensitized from real people's real experience').

142 Corbière v. Canada (Minister of Indian and Northern Affairs) [1999] 2 S.C.R. 203.
} 
analogous ground was answered in the positive. In Law $\mathrm{v}$ Canada, an age limit on survivor benefits was challenged by a young widow, ultimately unsuccessfully. However, the definition of analogous grounds was expanded in a way that inspired hope for acknowledging intersectional categories. According to the Supreme Court, any distinction based on one or more personal characteristics is deemed as being based on an analogous ground when it imposes a burden upon or withholds a benefit from the claimant in a manner reflecting stereotypical application of presumed group or personal characteristics. ${ }^{143}$ Reasoning for an unanimous court, Iacobucci J explained that there was 'no... reason why a discrimination claim positing an intersection of grounds cannot be understood as analogous to or as a synthesis of the grounds listed in section $15(1) \cdot{ }^{144}$

While acknowledging intersectionality as analogous ground would not be an option for applying the Canadian Human Rights Act with its closed list of grounds, understanding intersections of grounds as a synthesis of grounds would be applicable to this framework (and to EU Equality Law as well). Accordingly, there is the theoretical hope that courts would also acknowledge discrimination of women from a specific subgroup. However, the general 'tendency of the legal mind to want to compartmentalize ${ }^{145}$ has been said to prevent such development.

\section{(c) Interim conclusion on intersectionality}

The challenge of intersectionality has not been answered adequately by any legal order so far. This seems another task for future development of multi-faceted equality law.

So far, we can see that an open equality clause, as contained in the Canadian Constitution, facilitates acknowledging intersectional identities by adding them to the list of protected identities explicitly acknowledged. However, this additive approach to intersectionality is only half a step down the road to law's response to multi-faceted identity. It still forces individuals to align themselves with a fixed identity, although this identity may include several traits. The progress of being forced to categorise oneself as a black women or an Indian women is limited if one also wishes to have not only other traits acknowledged, but also the prospect of changing these traits. Accordingly, the legal mind still needs to be challenged to overcome its tendency to compartmentalise, in order to acknowledge all the intersections of human beings.

We can also conclude that meeting the challenge of multidimensionality is a consequence of striving for substantive equality: striving for substantive equality, law must recognise human multidimensionality. ${ }^{146}$ Substantive equality as an aim of equality

\footnotetext{
143 Law $v$ Canada (Minister of Employment and Immigration) (1999) 1 SCR 497, 534-541.

144 Law v Canada, 554.

145 Pothier, 'Connecting Grounds of Discrimination to Real People's Real Experiences', 60, with reference to Iyer.

146 Grabham, 'Law v Canada: New Directions for Equality under the Canadian Charter?', 649.
} 
law would require the law to respond to real experiences of people. These are characterised by 'the grounds' which should remain at the centre of equality law. ${ }^{147}$ However, the experience of people is also characterised by different grounds in any one individual. The proposal has thus been made to adopt a relationalist approach to equality law, which would lead to an acknowledgment of the ground-specific experience by those disadvantaged by and those profiting from discrimination at the same time. ${ }^{148}$ Disadvantage and profit may be experienced by the same individual on a variety of grounds. White women may be subjected to gender discrimination, and may be able to avoid some of it by employing ethnic minority women as household helpers, exploiting the weak labour market position of ethnic minority women. ${ }^{149}$ This example may suffice to illustrate the challenges of responding to the net of disadvantage and profit.

\section{QUESTIONS TO BE ANSWERED AS A CONSEQUENCE OF MULTIPLYING GROUNDS OF FORBIDDEN DISCRIMINATION IN EU EQUALITY LAW}

While this section started out with the question of whether multiplying grounds would inevitably lead to downgrading gender equality or whether it harbours the potential for law to respond better to women's social disadvantage, we arrive at the conclusion that there are even more questions that spring from the multiplication.

A tentative answer to the question raised in the first subsection, of whether the approach to equality law should be additive or integrated, has been found: while it is important to consider rationales of each single ground, an additive approach to the grounds is likely to dilute the complexity of questions posed by discrimination. An integrated approach is more likely to lead to solutions for reconciliation of conflicting rationales as well as the developments of a more convincing set of related conceptions of equality.

However, the integrated approach is also a challenging one. This article has not been able to develop answers to the question as to how different rationales should be reconciled, save from insisting on human autonomy to decide on one's own life as the decisive criterion against which any result of the reconciliation process should be judged. The conclusion, that multifaceted human reality and the fact that identities change over time require equality law to respond to intersectionality also brought more questions than answers. EU equality law will have to answer the question as to whether double or triple identities may be acknowledged as separate protected groups and whether and how it is possible for equality law to move beyond the group category altogether, without

147 See the arguments recounted above in note 120.

148 Pothier, 'Connecting Grounds of Discrimination to Real People's Real Experiences', 60.

149 This point is also made by L. Volpp, 'Feminism versus Multiculturalism’ 101 Columbian L. Rev. 1181 (2001), cited in Bartlett et al., Gender and Law, 1226. 
Broadening the Scope and the Norms of EU Gender Equality Law: Towards a

Multidimensional Conception of Equality Law

losing the grounds of forbidden discrimination as focus on real expectations of social disadvantage.

\section{\$4. CONCLUSION: TOWARDS A MULTIDIMENSIONAL CONCEPTION OF EU EQUALITY LAW?}

What possible new directions for EU equality law might we envisage, resulting from the developments discussed above? As was said at the beginning, the underlying assumption is that broadening the norms and scope of EU equality law requires a further development of these concepts. We will start with a notion of multidimensionality and proceed to the question of whether the new framework requires a coherent or rather a ground-specific interpretation. This links with the question as to whether EU equality law is capable of being construed to address intersectional discrimination. The overall conclusion shows that there are more open questions than ready made answers, rendering EU equality law an interesting subject for further research.

Evaluating and interpreting the three instruments based on Article 13 as part and parcel of EU equality law, we need to return to the main guiding principles set out in the 'Principles' section in the first chapter of the Treaty. On the one hand, there is Article 13 $\mathrm{EC}$, which elevates the combating of discrimination on six different grounds to one of the principles of Community law, placed neatly between Article 12 on nationality discrimination and Article 14 on realising the internal market. On the other hand, there is Article 3 (2) EC, which obliges the Community to combat inequalities and to promote equality between women and men, often shortened to the gender mainstreaming clause.

\section{A. NOTIONS OF MULTIDIMENSIONALITY}

The term 'multidimensionality' could refer to two distinctive characteristics of EU Equality Law:

On the one hand, multidimensionality could refer to different rationales and conceptions of equality. As was said earlier, most equality law theorists agree that different conceptions of equality should inform equality law. Accordingly, we could consider equality law as multidimensional in this first sense.

Multidimensionality could also refer to the number of grounds covered by equality law. Mono-dimensional equality law would thus characterise single-axis legislation, while multidimensional equality law would refer to multi-ground legislation. In this second sense, it is possible to use different qualifications. Multidimensional equality law could be used for any system that addresses several equalities, albeit in different instruments that could in themselves be characterised as mono-dimensional. As opposed to this formal 
Dagmar Schiek

notion, a substantive notion of multidimensionality in the second sense would require the legal regime to install some kind of reference between different grounds.

Without doubt, EU equality law is multidimensional in the first sense, as it employs different concepts of equality. A formal notion of equality is comprised in the narrow definition of direct discrimination, while the prohibition of indirect discrimination, the qualification of harassment as discrimination, and exceptions for pregnancy provisions as a narrow form of accommodating difference, as well as the obligation to accommodate difference of Framework Directive, Article 5, rely on a substantive notion of equality, as do the provisions allowing for positive action.

Whether EU equality law is multidimensional in the second sense is an open question so far. In this last section, it will be argued that for EU equality law to do justice to its own constructions and to the recognised need to address several grounds, it needs to become multidimensional in both dimensions. This is especially so as different conceptions of equality law are needed to achieve any single equality, and also to achieve equality for multi-faceted human beings in social reality.

\section{B. TOWARDS A COHERENT OR A GROUND-SPECIFIC FRAMEWORK?}

It has already been mentioned that there is a quest for developing ground-specific frameworks of equality law. We have, however, found some arguments in favour of an integrated approach to equality law in general. The question to be addressed here is whether there are specific reasons to consider the EU framework for equal treatment of persons as a coherent framework, to which an integrated approach can be applied.

As shaped by Directives 2000/43/EC, 2000/78/EC, 2002/73/EC and finally 2004/113/ EC, the Community framework eludes a clear classification as either additive or integrated. Directives such as 2000/43/EC and 2004/113/EC, focusing on one ground, seem to support an additive approach that has been typical for US legislation, but also for British legislation. This is supported by the fact that the whole framework is undoubtedly inspired by US and UK law, both being for once the root of social legislation. ${ }^{150}$ On the other hand, the separate instruments refer to each other in their recitals, ${ }^{151}$ stressing that multiple discrimination is to be combated. This would support the conclusion that the Community frame for equal treatment of persons goes beyond a single axis framework and follows an integrated approach. ${ }^{152}$

$150 \quad$ Nielsen, Gender Equality, 23.

151 Recital 14 of the Antiracism Directive reads: 'In implementing the principle of equal treatment irrespective of racial or ethnic origin, the Community should (....) aim to eliminate inequalities and to promote equality between women and men, especially since women are often the victims of multiple discrimination'. Recital 3 of the Framework Directive repeats this.

152 See Ellis, EU Anti-Discrimination Law, 210, arguing that these recitals exemplify the 'need for consistency of approach'. 
The method of functional interpretation which is typical for the ECJ's approach to Community law in general further supports a reading of all the legislative instruments on equal treatment of persons in a substantive way, guided by their purpose. In accordance with its international law basis, notably the CEDAW and the CERD, ${ }^{153}$ the purpose of EU equality law is to tackle social exclusion based on personal characteristics.

As an additional argument, the gender mainstreaming perspective may be utilised. If the Community is under a general obligation to promote equality between men and women, then surely its equality legislation has to be construed in such a way as to attain the general goal of gender equality. If we were to construe the framework on equal treatment of persons as being restricted to a number of separated single axis approaches, there would be serious drawbacks from a gender perspective.

There are certainly individuals who only suffer from one form of discrimination. For example, white women - considered as belonging to the majority ethnicity, claiming membership in the majority religion and living a heterosexual life without being regarded as disabled or too old or too young - will only suffer discrimination on grounds of their sex. Men considered as belonging to a minority ethnicity, claiming membership in the majority religion and living a heterosexual life without being regarded as disabled or too old or too young will only suffer discrimination on grounds of their ethnicity. White men considered as disabled, but also as belonging to majority religion and majority ethnicity, leading a heterosexual life will only suffer discrimination on grounds of their disability. This list could be prolonged endlessly. If we were to continue, we would find that most persons who only suffer from one kind of discrimination are male. Accordingly, an additive approach to equality law, focusing on single issues only, is more suited to respond to the reality of men than of women. We would thus conclude that an additive approach is inherently discriminating to the detriment of the majority of women. Viewed in this way, such an approach leads to structural gender discrimination. Accordingly, the gender equality clause requires us to construe EU equality law from an integrated perspective rather than from an additive approach.

All this requires the lawyer to read as much coherence into EU equality law as possible. There are, however, limits to this. First of all, secondary legislation for equalities contains different legal approaches for different grounds. For example, discriminating by withholding reasonable accommodation is only prohibited in relation to disability, ${ }^{154}$ but not in relation to gender or religion, although there are factual settings in which gender or

153 See Holtmaat and Tobler in this issue.

154 Article 5 of Directive 2000/78/EC obliges employers to provide 'reasonable accommodation in order to guarantee compliance with the principle of equal treatment in relation to persons with disabilities'. Reasonable accommodation is defined as taking 'appropriate measures, where needed in a particular case, to enable a person with a disability to have access to, participate in or advance in employment or to undergo training, unless such measures would impose a disproportionate burden on the employer.' The definition - read together with recital No 16 of the directive, saying that the provision of measures to accommodate the needs of the disabled plays an important role in combating discrimination - clarifies 
Dagmar Schiek

religious tolerance would be aided by reasonable accommodation. ${ }^{155}$ On the other hand, given the restrictions imposed by the individualistic definition of reasonable accommodation discrimination in that directive, ${ }^{156}$ future development of disability discrimination law in the EU might show that the concept of indirect discrimination has advantages over reasonable accommodation. While reasonable accommodation is only to be given upon individual request, a prohibition of indirect discrimination can be construed as to require employers and providers to implement non-discriminating structures with foresight. Secondly, the equality directives differ in their scopes for justifications of discrimination. This will lead to considerable difficulties with upholding consistencies where justifications contradict each other and make the legal assessment of discrimination based on cross related grounds next to impossible. To give just one example: ${ }^{157}$ age discrimination enjoys more exceptions than any other form of discrimination. Upper age limits will often be detrimental to women or those considered an ethnic minority. Can a business rely on one of the numerous exceptions to age discrimination and expect that the effects on gender and ethnic relations are not considered by equality lawyers? The third limit to an integrated approach under EU equality law is the hierarchies that have been established by different scopes of application for all the directives. Certainly, there may be hierarchies even under an integrated approach. Preferring one ground - race and ethnicity - over all others is, however, incompatible with an integrated approach. Developing an integrated approach, EU equality law also needs to extend the scope of application for more than one equality to goods and services, education and social advantages. Directive 2004/113/EC is a step towards this. It might also be a step towards an integrated approach.

\section{ADDRESSING INTERSECTIONAL DISCRIMINATION IN EU LAW ?}

The experiences from the UK, US and Canada suggest that intersectional discrimination is not easy to address. The question is whether the Community framework can be

that this is indeed an additional concept of prohibiting discrimination and not some form of positive action (the same position is taken by Waddington/ Hendriks, 'The Expanding Concept of Employment Discrimination in Europe: From Direct and Indirect Discrimination to Reasonable Accommodation Discrimination', 425-6.

155 Examples from US American law include the following: a transport firm refusing to acquire lorries equipped with power steering could lose a court case on sex discrimination, as the resulting requirement for power muscles in their employees is indirectly discriminatory against women (M. Kelman, 'Market Discrimination and Groups', 53 Stanford L. Rev. 834 (2001). A pizza service rejecting applications from male employees wearing a beard could be considered as indirectly discriminating against black men (C. Jolls, 'Antidiscrimination and Accommodation' 115 Harv. L. Rev. 642 (2001), 653-656.

156 This individualistic trait is apparent from the words 'in a particular case', and also from the purpose of the obligation to 'enable a person' to participate.

157 There are more examples in Schiek, 'A New Framework of Equal Treatment of Persons in EC Law', 31112. 
construed in such a way as to include a prohibition of discrimination on grounds of, for example, being a disabled woman from an ethnic minority. A coherent framework and an integrated approach would need to meet this challenge.

Subjecting EU equality law to an integrated approach is, of course, the first step towards acknowledging persons suffering from intersectional discrimination as protected groups. Again, the gender mainstreaming perspective supports this view.

Accordingly, the Community framework on equal treatment of persons needs to be read as prohibiting not only discrimination on single grounds, but also on combined grounds. Admittedly, this reasoning would have its limits in areas where only one or two grounds are addressed, such as goods and services (gender and race discrimination prohibited) or education (only race discrimination prohibited). However, as regards employment and occupation, EU equality law encompasses all grounds, albeit with a different set of exceptions.

In addition, the notion of intersectional discrimination being addressed by Community law needs to be further fleshed out. Only if cases of intersectional discrimination are brought before European courts will we know how these theoretical conceptions may be addressed in real life. Responding to real life, Community (gender) equality law should, however, distinguish between different forms of gender discrimination such as discrimination against women who are ascribed a minority race or ethnicity or who chose a non-heterosexual life style or are considered disabled.

The purposive method of interpreting any norm of Community law would lend itself to assisting the Community courts to actually acknowledge these dimensions of multidimensionality. It would not do justice to the purposes of all the equality instruments taken together to deny the specific situation of intersected human beings. Accordingly, disabled women from an ethnic minority background should be able to establish a prima facie case for indirect discrimination against any employment practice that would prove disproportionately detrimental to them.

\section{MORE OPEN QUESTIONS THAN READY-MADE ANSWERS}

As has become apparent, theorizing EU equality law in its present state, with case law on the new directives absent, necessarily produces more questions than answers. However, this is of course a window of opportunity for EU law doctrine to pave the way for a sophisticated development of this new and exiting area of law.

One pavestone should lead to the conclusion that EU equality law, aiming to overcome structural disadvantage, should focus on those persons combining several characteristics on grounds of which they are bound to suffer multiple disadvantage. This requires EU equality law to address intersectional discrimination adequately.

The next pavestone is then an integrated approach to equality law, which urges the lawyer to take into account divergent rationales and conceptions. These may conflict at times. A method to reconcile diverse rationale without proposing a clear hierarchy still 
needs to be found. This method should, perhaps, begin by diminishing hierarchies between equalities in EU law, without giving in to the most eminent danger of multidimensional equality law. This danger is that many grounds that are not equivalent in terms of potential for social exclusion are treated equally, leaving the most serious discrimination in a muddle of grounds. ${ }^{158}$ EU equality law cannot avoid an integrated approach including reasoned focuses on key equalities forever. ${ }^{159}$

Mainstreaming equality - including gender equality - could serve as a strategy to avoid hierarchies wherever possible. It will become a new and more complex method than just gender mainstreaming as soon as the need to mainstream equality in general is acknowledged. Considering the effects of each and any policy on those protected against discrimination is - luckily - a task more suitable to sociologists than to lawyers.

The consequences of these demands still await further development. Those who have been engaged in discourses on equality for a long time will be best equipped to contribute to this. It remains to be seen whether the EU institutions will sustain their reluctance to rely on experiences gained in gender equality law, after all the oldest body of Community equality law. Likewise, it remains to be seen whether gender equality lawyers are prepared to meet the challenge to focus on those with multiple disadvantage instead of those for whom gender discrimination is the only discrimination experienced.

158 See R. Holtmaat, 'Stop de uitholling van het discriminatiebegrip! Een herbezinning op het onderscheid tussen discriminatie en ongelijke behandeling', 78 Nederlandse Juristenblad 1266 (2003).

159 See Cooper, Challenging Diversity, 193-195, proposing the term 'organising principle' as the one distinguishing simple inequalities such as those between smokers and non-smokers from the important ones, such as those based on gender, race and class, possibly also sexual orientation. For any social asymmetry to qualify as organising principle, Cooper requires unequal treatment as a necessary, but not sufficient element. In addition, the unequal treatment must have 'the capacity to shape other dimensions of the social' and also 'impact significantly on social dynamics such as the intimate/impersonal, capitalism and community boundary maintenance'. Zappone, Charting the Equality Agenda, proposes the term 'Marker of Difference' for those grounds that are focus points of an integrated equality strategy, without, however, really questioning the legislative decisions made in the Republic of Ireland and Northern Ireland (at 84-85). I had started my first cautious proposals on hierarchies on normative approaches (relying on international law as the consensus of the civilised world) and also on functions of the grounds of forbidden discrimination, and had remarked that characteristics deemed beyond control of those individuals which possess them should more likely be regarded as candidates for a strict prohibition of discrimination ('A New Framework of Equal Treatment of Persons in EC Law'). 